Marquette University

e-Publications@Marquette

School of Dentistry Faculty Research and

Publications

Dentistry, School of

$1-2016$

\title{
A Systematic Review of Recall Regimen and Maintenance Regimen of Patients with Dental Restorations. Part 2: Implant- Borne Restorations
}

\author{
Avinash S. Bidra \\ University of Connecticut Health Center \\ Diane M. Daubert \\ University of Washington School of Dentistry \\ Lily T. Garcia \\ University of lowa College of Dentistry \& Dental Clinics \\ Marissa F. Gauthier \\ University of Connecticut Health Center \\ Timothy F. Kosinski \\ University of Detroit Mercy School of Dentistry
}

See next page for additional authors

Follow this and additional works at: https://epublications.marquette.edu/dentistry_fac

Part of the Dentistry Commons

\section{Recommended Citation}

Bidra, Avinash S.; Daubert, Diane M.; Garcia, Lily T.; Gauthier, Marissa F.; Kosinski, Timothy F.; Nenn, Conrad A.; Olsen, John A.; Platt, Jeffrey A.; Wingrove, Susan S.; Chandler, Nancy Deal; and Curtis, Donald A., "A Systematic Review of Recall Regimen and Maintenance Regimen of Patients with Dental Restorations. Part 2: Implant-Borne Restorations" (2016). School of Dentistry Faculty Research and Publications. 138. https://epublications.marquette.edu/dentistry_fac/138 


\section{Authors}

Avinash S. Bidra, Diane M. Daubert, Lily T. Garcia, Marissa F. Gauthier, Timothy F. Kosinski, Conrad A. Nenn, John A. Olsen, Jeffrey A. Platt, Susan S. Wingrove, Nancy Deal Chandler, and Donald A. Curtis 


\title{
A Systematic Review of Recall Regimen and Maintenance Regimen of Patients with Dental Restorations. Part 2: Implant-Borne Restorations
}

\author{
Avinash S. Bidra \\ Department of Reconstructive Sciences, \\ University of Connecticut Health Center, \\ Farmington, CT \\ Diane M. Daubert \\ Department of Periodontics, \\ University of Washington School of Dentistry, \\ Seattle, WA \\ Lily T. Garcia \\ Office of the Dean, \\ University of Iowa College of Dentistry \& Dental Clinics, \\ Iowa City, IA \\ Marissa F. Gauthier \\ L.M. Stowe Library, \\ University of Connecticut Health Center, \\ Farmington, CT
}




\author{
Timothy F. Kosinski \\ Department of Restorative Dentistry, \\ University of Detroit Mercy School of Dentistry, \\ Detroit, $M I$ \\ Conrad A. Nenn \\ Department of General Dental Sciences, \\ Marquette University School of Dentistry, \\ Milwaukee, WI \\ John A. Olsen \\ Private Practice, \\ Franklin, WI \\ Jeffrey A. Platt \\ Department of Biomedical and Applied Sciences, \\ Division of Dental Biomaterials, \\ Indiana University School of Dentistry, \\ Indianapolis, IN \\ Susan S. Wingrove \\ Private Practice Hygienist, Regeneration Research, \\ Missoula, MT \\ Nancy Deal Chandler \\ American College of Prosthodontists and ACP Education \\ Foundation, \\ Chicago, IL \\ Donald A. Curtis \\ Department of Preventive \& Restorative Dental Sciences, \\ UCSF School of Dentistry, \\ San Francisco, CA
}


NOT THE PUBLISHED VERSION; this is the author's final, peer-reviewed manuscript. The published version may be accessed by following the link in the citation at the bottom of the page.

\begin{abstract}
Purpose: To evaluate the current scientific evidence on patient recall and maintenance of implant-supported restorations, to standardize patient care regimens and improve maintenance of oral health. An additional purpose was to examine areas of deficiency in the current scientific literature and provide recommendations for future studies.
\end{abstract}

Materials and Methods: An electronic search for articles in the English language literature from the past 10 years was performed independently by multiple investigators using a systematic search process. After application of predetermined inclusion and exclusion criteria, the final list of articles was reviewed to meet the objectives of this review.

Results: The initial electronic search resulted in 2816 titles. The systematic application of inclusion and exclusion criteria resulted in 14 articles that satisfied the study objectives. An additional 6 articles were added through a supplemental search process for a total of 20 studies. Of these, 11 were randomized controlled clinical trials, and 9 were observational studies. The majority of the studies (15 out of 20) were conducted in the past 5 years and most studies were conducted in Europe (15), followed by Asia (2), South America (1), the United States (1), and the Middle East (1). Results from the qualitative data on a combined 1088 patients indicated that outcome improvements in recall and maintenance regimen were related to (1) patient/treatment characteristic (type of prosthesis, type of prosthetic components, and type of restorative materials); (2) specific oral topical agents or oral hygiene aids (electric toothbrush, interdental brush, chlorhexidine, triclosan, water flossers) and (3) professional intervention (oral hygiene maintenance, and maintenance of the prosthesis).

Conclusions: There is minimal evidence related to recall regimens in patients with implant-borne removable and fixed restorations; however, a considerable body of evidence indicates that patients with implant-borne removable and fixed restorations require lifelong professional recall regimens to provide biological and mechanical maintenance, customized for each patient. Current evidence also demonstrates that the use of specific oral topical agents and oral hygiene aids can improve professional and at-home maintenance of implant-borne restorations. There is evidence to demonstrate differences in mechanical and biological maintenance needs due to differences in prosthetic materials and designs. Deficiencies in existing evidence compel the forethought of creating clinical practice guidelines for recall and maintenance of patients with implant-borne dental restorations.

Implant-supported restorations often represent a favorable alternative to conventional dental prostheses due to improved support, comfort, and function. Treatment plans to address patient needs using implant-borne restorations range from implant-supported single crowns, implant-supported partial fixed dental prostheses (FDP), implant-supported complete arch FDPs, implant-supported partial removable dental prostheses (RDP) to implant-supported complete RDPs (overdentures). Each type of restoration/prosthesis requires

Journal of Prosthodontics, Vol 25, No. S1 (January 2016): pg. S16-S31. DOI. This article is @ Wiley and permission has been granted for this version to appear in e-Publications@Marquette. Wiley does not grant permission for this article to be further copied/distributed or hosted elsewhere without the express permission from Wiley. 
careful planning, meticulous coordination of care, and a long-term partnership with the patient to maintain an enduring result. This includes an appropriate patient recall regimen and professional as well as at-home maintenance. ${ }^{1-20}$ The fabrication of implant restorations also represents a considerable investment of time and resources, with the anticipation of an enduring result by patients and clinicians. Current guidelines for the maintenance of implant restorations are poorly defined and often based on traditional protocols for patients with natural dentition rather than what is most suitable for maintenance of implant restorations and supporting tissues. Therefore, maintenance guidelines for patients with implant-borne removable and/or fixed restorations are necessary to minimize the risk for restoration failure, peri-implant disease and failure of the supporting implants themselves. Furthermore, maintenance protocols in healthy adult patients with implant-borne restorations may be significantly different when compared to patients with tooth-borne restorations, no restorations, or patients with acute or chronic oral and systemic diseases.

Maintenance programs in dentistry have often focused on younger patient cohorts and on assessing and managing chronic processes such as caries or periodontal disease. ${ }^{21-24}$ The typical 6month patient recall interval used by dentists worldwide was advocated by the American Academy of Dental Science as early as 1879. ${ }^{24,25}$ Later, the American Dental Association (ADA) also advocated the 6-month recall in its first oral health patient brochure. The 6month interval for dental visits was also promoted by a popular dentifrice commercial (Ipana; Bristol-Meyers Company, New York, NY) in the 1930s, eventually resulting in wide acceptance as a standard in the dental insurance industry. ${ }^{24,25}$

Traditionally, patients at both lower and higher risk for dental disease have been placed on 6-month recalls with the logic of early detection, prevention of disease, and oral cancer screening. ${ }^{24,26}$ Recall programs based on risk assessment of potential complications such as caries or periodontal disease have become increasingly accepted in dentistry. ${ }^{27-29}$ Despite the logic of 6-month recalls, recent systematic reviews determined that 6 -month recall protocols for caries prevention were not supported by the literature, and that existing recall patterns in dentistry did not account for varying risk patterns seen in 
patients. 24,30 These authors concluded that clinicians might consider assigning recall intervals based on the patients' risk of developing dental disease rather than using 6-month intervals as the standard recall interval. Basing recall schedules on patient-specific needs to avoid complications has been implemented in recall maintenance programs for diabetic patients with good success. ${ }^{31}$

Implant-supported single crowns and implant-supported FDPs have favorable survival rates but considerable mechanical and biologic complications in the long term. ${ }^{32-37}$ Ten-year survival rates for implants supporting single crowns were reported as approximatively $95 \%, 33$ and implant-supported FDPs reported as $93 \%$. $^{32}$ Notably, $33.6 \%$ of the patients had a mechanical and/or biologic complication in the first 5 years, prompting the authors to recommend that patients be placed in a well-structured maintenance program. ${ }^{32}$ Mechanical complications of implant-supported FDPs have been reported to include veneering material fractures $(13.5 \%)$, screw loosening $(5.3 \%)$, loss of retention of cemented FDPs $(4.7 \%)$, and screw fracture $(1.3 \%)$ over a 5 -year period. ${ }^{32}$

Biologic complications with implant-supported prostheses include bone loss and associated midfacial soft tissue recession and inflammatory peri-implant diseases including peri-implant mucositis and "peri-implantitis," which have been difficult to quantify due to authors using differing criteria; however, peri-implantitis has been estimated to occur in approximately $8.5 \%$ of patients treated with implants evaluated over a 5 -year period. ${ }^{32}$ The primary clinical criteria to identify biologic complications include periodontal probing depths $\geq$ $5 \mathrm{~mm}$ and bleeding on probing of $\geq 30 \%$, which may increase the risk of implant loss over a mean follow-up of 7.9 years. ${ }^{32}$ It has also been reported that failing implants have been associated with higher plaque biofilm levels than successful implants. ${ }^{37}$ This underscores the value of implementing an oral self-care and professional oral care regimen. The benefit for a recall program was also shown in a study of 80 patients diagnosed with peri-implant mucositis, where those not participating in a structured recall program progressed to peri-implantitis at more than twice the rate as patients participating in a recall maintenance program. $^{8}$

Journal of Prosthodontics, Vol 25, No. S1 (January 2016): pg. S16-S31. DOI. This article is @ Wiley and permission has been granted for this version to appear in e-Publications@Marquette. Wiley does not grant permission for this article to be further copied/distributed or hosted elsewhere without the express permission from Wiley. 
The purpose of this systematic review was to evaluate the current scientific evidence on patient recall and maintenance of implant-supported restorations, to standardize patient care regimens, and to make recommendations to improve maintenance of oral health. An additional purpose was to examine areas of deficiency in the current scientific evidence and provide recommendations for future studies. For the purposes of this systematic review, patient recall was defined as the routine follow-up of patients following insertion of implant-borne dental restorations. Professional maintenance was defined as the procedures and guidance provided by the dentist and dental auxiliaries. At-home maintenance was defined as the daily oral hygiene and maintenance routine that patients perform to maintain their implant restorations, any existing natural teeth, and restorations and supporting tissues.

\section{Materials and methods}

An independent electronic search of the English language literature was performed by two investigators $(A B, D C)$ using the PubMed search engine and Cochrane Library database. The specific search terms, search string, and limits are presented in Table 1 . The specific PICO question for this systematic review was: in patients with implant-borne restorations, does one specific recall regimen and dental maintenance regimen compared to others, or no regimen, improve clinical outcomes and patient care, and optimize maintenance of oral health? The period searched was from January 1, 2004 to December 31,2014 . The only search limits applied to the electronic search were the English language, the search period, and clinical studies (Table 1). The anticipated implant-borne restorations of interest in this study were: implant-supported single crowns, implant-supported partial FDPs, implant-supported complete FDPs, implant-supported partial RDPs, and implant-supported complete RDPs. The predetermined inclusion criteria were: (1) English language article in a peer-reviewed journal; (2) any clinical study published between January 1, 2004 and December 31, 2014; and (3) any clinical study with the primary focus on patient recall regimen, professional maintenance, or at-home maintenance regimen for implant-borne restorations, in healthy patients. The predetermined exclusion criteria were: (1) articles that did not pertain to items described in the inclusion criteria; (2) articles

Journal of Prosthodontics, Vol 25, No. S1 (January 2016): pg. S16-S31. DOI. This article is (C) Wiley and permission has been granted for this version to appear in e-Publications@Marquette. Wiley does not grant permission for this article to be further copied/distributed or hosted elsewhere without the express permission from Wiley. 
NOT THE PUBLISHED VERSION; this is the author's final, peer-reviewed manuscript. The published version may be accessed by following the link in the citation at the bottom of the page.

that did not pertain to the objectives of the systematic review; (3) articles that did not describe data on recall and maintenance of patients with implant-borne restorations; (4) articles that described data on unhealthy patients or patients with peri-implantitis; (5) articles with a focus on outcomes after implant surgery; (6) review articles or technique articles without associated clinical study and data; (7) patients or data being repeated in other included articles; and (8) article description that would not allow extraction of qualitative or quantitative data related to objectives of the study.

Table 1. Description of the search terms and search process used in the PubMed search engine

\begin{tabular}{|c|c|c|}
\hline Search & Query & Results \\
\hline${ }^{*} 1$ & 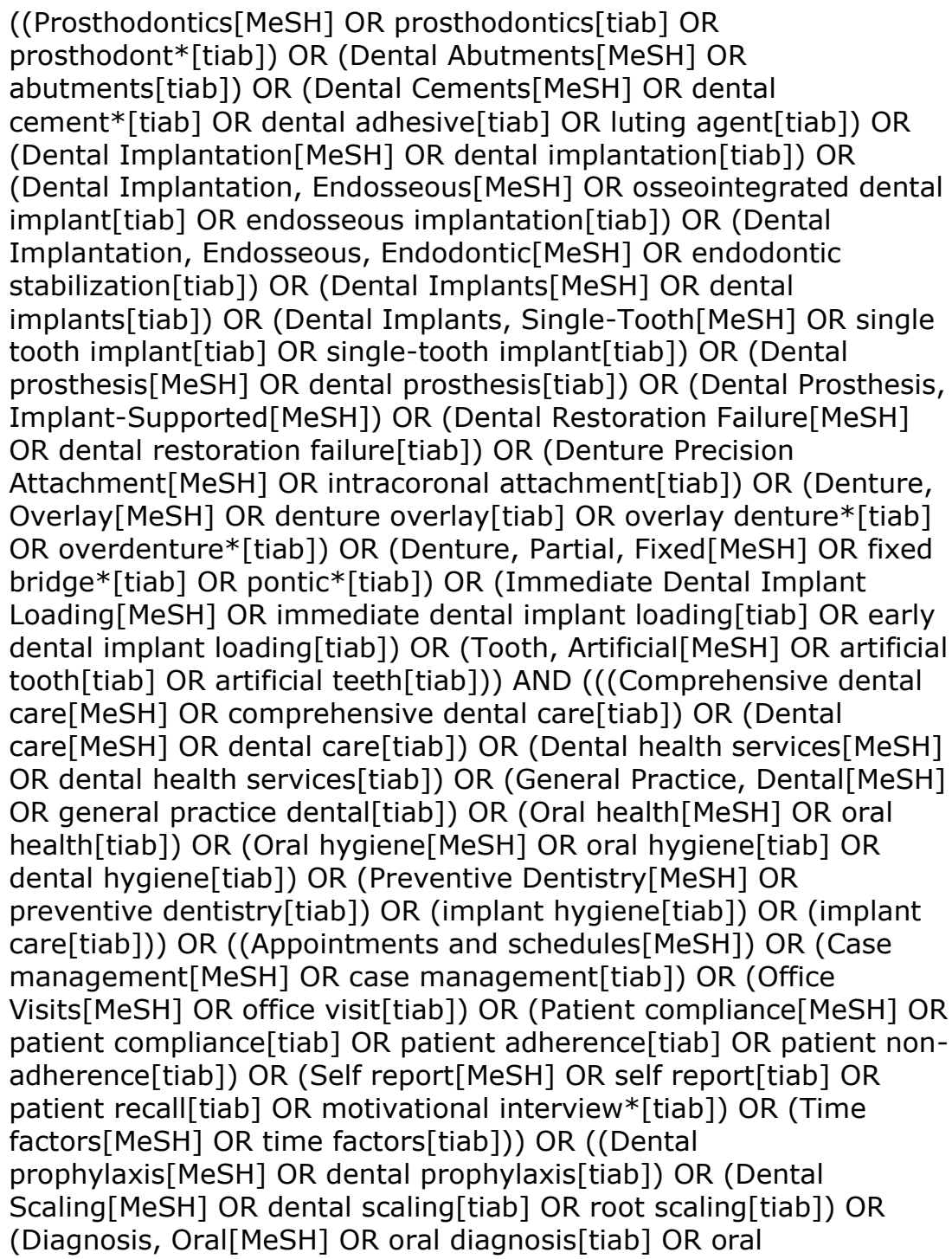 & 18,803 \\
\hline
\end{tabular}

Journal of Prosthodontics, Vol 25, No. S1 (January 2016): pg. S16-S31. DOI. This article is @ Wiley and permission has been granted for this version to appear in e-Publications@Marquette. Wiley does not grant permission for this article to be further copied/distributed or hosted elsewhere without the express permission from Wiley. 


\begin{tabular}{|c|c|c|}
\hline \multirow[t]{2}{*}{ Search } & Query & Results \\
\hline & $\begin{array}{l}\text { examination[tiab]) OR (Periodontal Debridement[MeSH] OR } \\
\text { periodontal debridement[tiab]) OR (Root planing[MeSH] OR root } \\
\text { planing[tiab]) OR (Periodontal Index[MeSH] OR periodontal } \\
\text { index[tiab] OR bleeding on probing[tiab] OR gingival index[tiab] OR } \\
\text { gingival bleeding on probing[tiab])) OR ((Dental Devices, Home } \\
\text { Care[MeSH] OR dental floss[tiab]) OR (Toothbrushing[MeSH] OR } \\
\text { toothbrushing[tiab]) OR (Toothpastes[MeSH] OR toothpaste*[tiab]) } \\
\text { OR (Dentifrices[MeSH] OR dentifrice[tiab]) OR (Mouthwashes[MeSH] } \\
\text { OR mouthwash[tiab]) OR (Chewing Gum[MeSH] OR chewing } \\
\text { gum[MeSH]) OR (Triclosan[MeSH] OR triclosan[tiab]) OR } \\
\text { (interproximal brush[tiab]) OR (proxabrush[tiab]) OR (Mouth } \\
\text { protectors[MeSH] OR mouth protectors[tiab] OR mouth piece[tiab] } \\
\text { OR mouthpiece[tiab] OR mouth guard[tiab]))) }\end{array}$ & \\
\hline \#2 & ${ }^{\#} 1+$ English & 16,574 \\
\hline \#3 & ${ }^{*} 2+$ Humans & 13,783 \\
\hline$\# 4$ & $\# 3+2004$-present & 7,115 \\
\hline \#5 & $\begin{array}{l}\text { \#4 + Limit to Clinical Trial, Comparative Study, Controlled Clinical } \\
\text { Trial, Multicenter Study, Observational Study, Randomized } \\
\text { Controlled Trial, or Validation Study }\end{array}$ & 2,816 \\
\hline
\end{tabular}

The electronic search process was systematically conducted in three stages. A PRISMA ${ }^{38}$ (Preferred Reporting Items for Systematic Reviews and Meta-analyses) format was used as a filter to remove duplicate articles and to ensure a systematic search process. In stage 1 , the investigators independently screened all relevant titles of the electronic search, and any disagreement was resolved by discussion. In situations where the application of the exclusion criteria was not clear, the controversial article was included for consideration in the abstract stage. In stage 2, the investigators independently analyzed the abstracts of all selected titles, and disagreements were resolved by discussion. In situations of uncertainty, the abstract was included for the subsequent full-text stage. After the application of the exclusion criteria, the definitive list of articles was screened at stage 3 by the investigators to extract qualitative and quantitative data (when available). A supplemental electronic search for articles from Scopus, Google Scholar and CINAHL (Cumulative Index to Nursing and Allied Health Literature) search engines along with a hand search of references of all included articles was conducted using systematic methods. Additionally, articles that had a lag time to appear on the PubMed search engine were also screened for the three stages, as part of the supplemental search. Data from all included studies were then tabulated, analyzed, and compared to satisfy the objectives of the review.

Journal of Prosthodontics, Vol 25, No. S1 (January 2016): pg. S16-S31. DOI. This article is @ Wiley and permission has been granted for this version to appear in e-Publications@Marquette. Wiley does not grant permission for this article to be further copied/distributed or hosted elsewhere without the express permission from Wiley. 
NOT THE PUBLISHED VERSION; this is the author's final, peer-reviewed manuscript. The published version may be accessed by following the link in the citation at the bottom of the page.

\section{Results}

The initial electronic search using the specific search terms from the PubMed search engine resulted in a total of 2816 titles, out of which 83 abstracts were applicable to the study. Further scrutiny resulted in detailed analysis of 44 full-text articles from which 30 articles were excluded. Incorporating a supplemental and electronic hand search process and systematic exclusion eventually resulted in 20 full-text articles, all of which reported data on patient recall and maintenance of dental restorations on implants (Fig 1). These 20 studies were included for qualitative data extraction and analysis (Table 2). The authors did not identify a significant amount of quantitative data from the data extraction, which may be related to the nature of the topic and PICO question posed in this systematic review. Therefore, no statistical analysis was completed. 
NOT THE PUBLISHED VERSION; this is the author's final, peer-reviewed manuscript. The published version may be accessed by following the link in the citation at the bottom of the page.

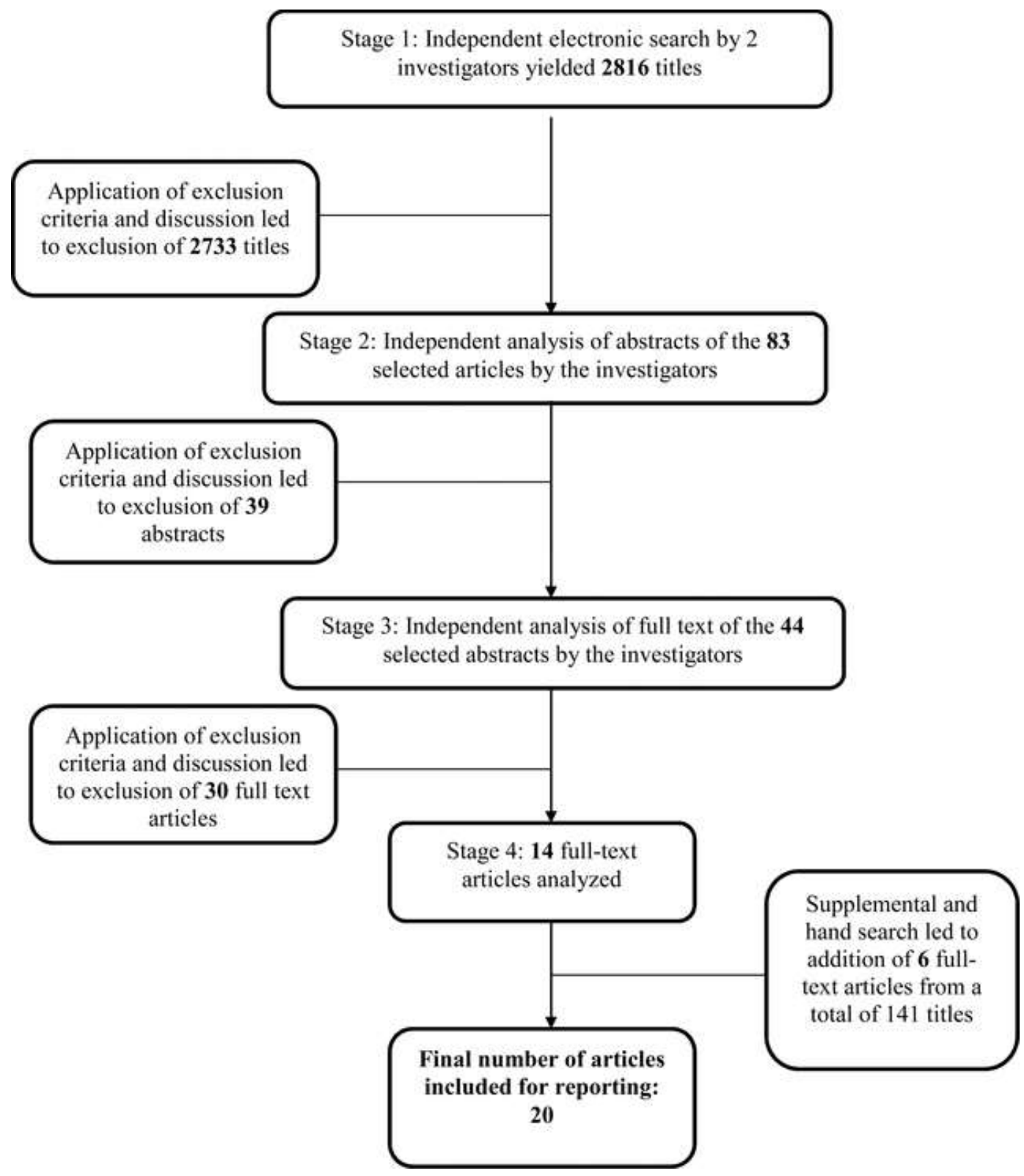

Figure 1. Systematic search process.

Journal of Prosthodontics, Vol 25, No. S1 (January 2016): pg. S16-S31. DOI. This article is @ Wiley and permission has been granted for this version to appear in e-Publications@Marquette. Wiley does not grant permission for this article to be further copied/distributed or hosted elsewhere without the express permission from Wiley. 
NOT THE PUBLISHED VERSION; this is the author's final, peer-reviewed manuscript. The published version may be accessed by following the link in the citation at the bottom of the page.

Table 2. Descriptive data from the 20 included studies that reported on recall and maintenance of implant-borne restorations

\begin{tabular}{|c|c|c|c|c|c|c|c|}
\hline $\begin{array}{c}\text { Author and } \\
\text { year }\end{array}$ & $\begin{array}{l}\text { Type of } \\
\text { study }\end{array}$ & $\begin{array}{l}\text { Study } \\
\text { setting }\end{array}$ & $\begin{array}{c}\text { Geographic re } \\
\text { gion }\end{array}$ & $\begin{array}{c}\text { Number } \\
\text { of } \\
\text { patients }\end{array}$ & $\begin{array}{c}\text { Age of } \\
\text { patien } \\
\text { ts }\end{array}$ & $\begin{array}{c}\text { Type of } \\
\text { implant- } \\
\text { borne } \\
\text { restoratio } \\
\text { ns } \\
\text { included } \\
\text { in the } \\
\text { study }\end{array}$ & $\begin{array}{c}\text { Study } \\
\text { sponsors } \\
\text { hip }\end{array}$ \\
\hline
\end{tabular}

1. NR: not reported; RCT: randomized clinical trial; FDP: fixed dental prosthesis.

\begin{tabular}{|c|c|c|c|c|c|c|c|}
\hline $\begin{array}{l}\text { Magnuson et } \\
\text { al }(2013)^{1}\end{array}$ & RCT & University & USA & 44 & $\begin{array}{l}\text { Range: } \\
22 \text { to } \\
62 \\
\text { years } \\
\text { Mean } \\
\text { age: } \\
\text { NR }\end{array}$ & $\begin{array}{l}\text { Implant- } \\
\text { supported } \\
\text { crowns }\end{array}$ & $\begin{array}{l}\text { Corporate; } \\
\text { Water Pik, } \\
\text { Inc. }\end{array}$ \\
\hline $\begin{array}{l}\text { Morawiec et } \\
\text { al }(2013)^{2}\end{array}$ & $\mathrm{RCT}$ & $\begin{array}{l}\text { University } \\
\text { and } \\
\text { private } \\
\text { practice }\end{array}$ & Europe (Poland) & 16 & $\begin{array}{l}\text { Range: } \\
22 \text { to } \\
65 \\
\text { years } \\
\text { Mean } \\
\text { age: } \\
\text { NR }\end{array}$ & $\begin{array}{l}\text { Implant- } \\
\text { supported } \\
\text { crowns, } \\
\text { FDPs, and } \\
\text { overdentur } \\
\text { es }\end{array}$ & $\begin{array}{l}\text { Product } \\
\text { support by } \\
\text { Nihon } \\
\text { Natural } \\
\text { Food Co. } \\
\text { Ltd and } \\
\text { university } \\
\text { support for } \\
\text { the study }\end{array}$ \\
\hline $\begin{array}{l}\text { Mussano et } \\
\text { al }(2013)^{3}\end{array}$ & RCT & University & Europe (Italy) & 15 & NR & $\begin{array}{l}\text { Implant } \\
\text { overdentur } \\
\text { es in the } \\
\text { mandible }\end{array}$ & None \\
\hline $\begin{array}{l}\text { Swierkot et } \\
\text { al }(2013)^{4}\end{array}$ & $\begin{array}{l}\text { RCT- } \\
\text { single- } \\
\text { blinded }\end{array}$ & University & $\begin{array}{l}\text { Europe } \\
\text { (Germany) }\end{array}$ & 83 & $\begin{array}{l}\text { Range: } \\
45 \text { to } \\
78 \\
\text { years } \\
\text { Mean } \\
\text { age: } \\
59.8\end{array}$ & $\begin{array}{l}\text { Implant- } \\
\text { supported } \\
\text { crowns }\end{array}$ & $\begin{array}{l}\text { Corporate; } \\
\text { Philips } \\
\text { Healthcare } \\
\text { Systems }\end{array}$ \\
\hline $\begin{array}{l}\text { Zou et al } \\
(2013)^{5}\end{array}$ & $\begin{array}{l}\text { Observatio } \\
\text { nal }\end{array}$ & University & Asia (China) & 30 & $\begin{array}{l}\text { Range: } \\
57 \text { to } \\
79 \\
\text { years } \\
\text { Mean } \\
\text { age: } \\
\text { NR }\end{array}$ & $\begin{array}{l}\text { Implant } \\
\text { overdentur } \\
\text { es in the } \\
\text { maxilla } \\
\text { with either } \\
\text { telescopic } \\
\text { crowns, } \\
\text { bars, or } \\
\text { locators }\end{array}$ & $\begin{array}{l}\text { National } \\
\text { governme } \\
\text { nt of China }\end{array}$ \\
\hline $\begin{array}{l}\text { De Siena et } \\
\text { al }(2012)^{6}\end{array}$ & $\mathrm{RCT}$ & University & Europe (Italy) & $\begin{array}{l}30 \text { ( } 23 \\
\text { patients } \\
\text { complete } \\
\text { d) }\end{array}$ & $\begin{array}{l}\text { Range: } \\
43 \text { to } \\
87 \\
\text { years } \\
\text { Mean } \\
\text { age: } \\
62.3 \pm \\
9.9\end{array}$ & $\begin{array}{l}\text { Mandibular } \\
\text { 4-implant- } \\
\text { supported } \\
\text { metal-resin } \\
\text { fixed } \\
\text { prosthesis } \\
\text { or metal- } \\
\text { resin fixed } \\
\text { prosthesis } \\
\text { in the } \\
\text { anterior }\end{array}$ & $\begin{array}{l}\text { Product } \\
\text { support by } \\
\text { Curaden } \\
\text { Healthcare }\end{array}$ \\
\hline
\end{tabular}

Journal of Prosthodontics, Vol 25, No. S1 (January 2016): pg. S16-S31. DOI. This article is (C) Wiley and permission has been granted for this version to appear in e-Publications@Marquette. Wiley does not grant permission for this article to be further copied/distributed or hosted elsewhere without the express permission from Wiley. 
NOT THE PUBLISHED VERSION; this is the author's final, peer-reviewed manuscript. The published version may be accessed by following the link in the citation at the bottom of the page.

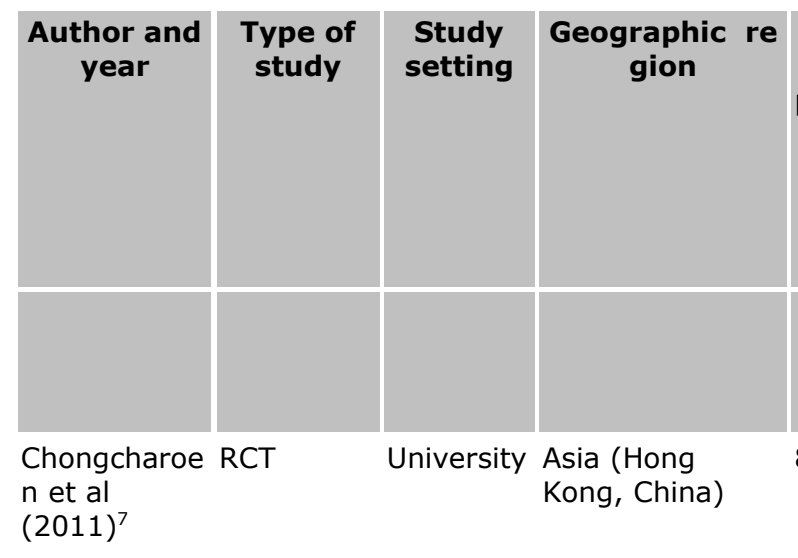

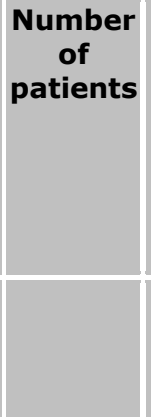
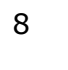

$(2011)^{7}$

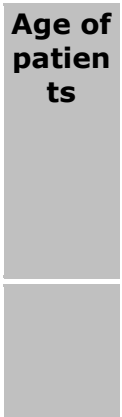

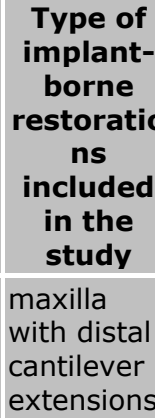

Range: Implant-

26 to supported

65 crowns

years

Mean

age:

NR

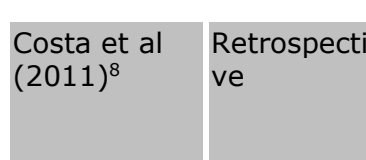

Fischer et al RCT

$(2011)^{9}$

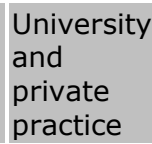

South America
(Brazil)

University Europe

(Sweden)

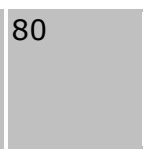

24

NR

NR implant-

$\begin{array}{ll}\text { Range: } & \text { Implant- } \\ \text { NR } & \text { supported nt } \\ \text { Mean } & \text { crowns and } \\ \text { age: } 50 & \text { FDPs }\end{array}$

Range: Maxillary None

Mean supported

age: 64 metal-resin

fixed

prosthesis
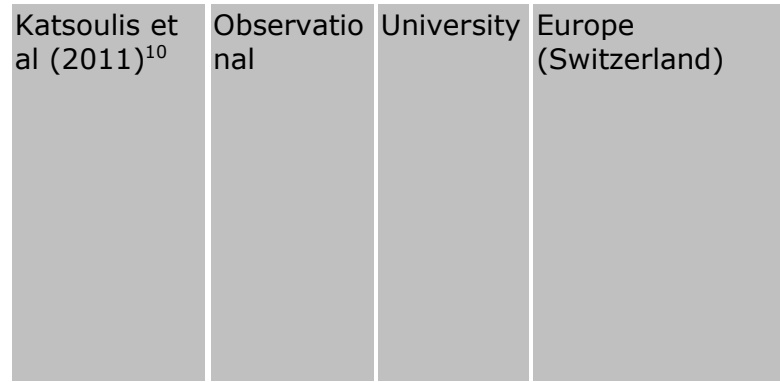

Akça et a $(2010)^{11}$

Observatio University Europe (Turkey) nal

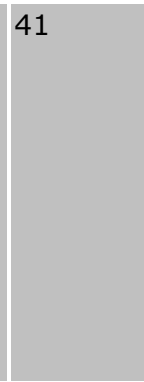

35

Range:
52 to
78
years
Mean
age:
NR

NR

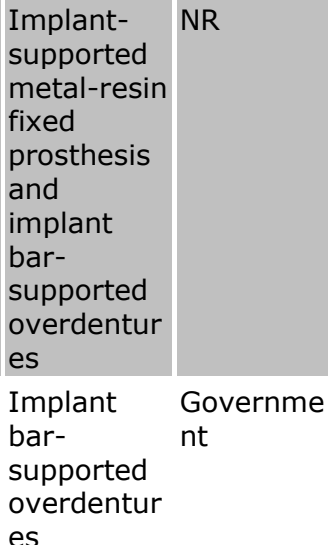

es

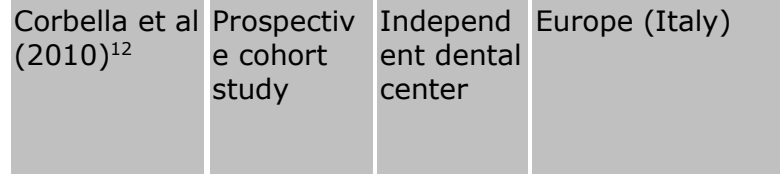

Rentsch-

Retrospecti University Europe

(Switzerland)

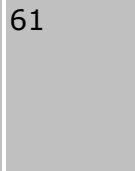

147
Kollar et al ve

$(2010)^{13}$

\begin{tabular}{|c|c|c|}
\hline $\begin{array}{l}\text { Range: } \\
\text { NR } \\
\text { Mean } \\
\text { age: } 54\end{array}$ & $\begin{array}{l}\text { Implant- } \\
\text { supported } \\
\text { metal-resin } \\
\text { fixed } \\
\text { prosthesis }\end{array}$ & None \\
\hline $\begin{array}{l}\text { Range: } \\
\text { NR } \\
\text { Mean } \\
\text { age: } 62\end{array}$ & $\begin{array}{l}\text { Maxillary } \\
\text { denture } \\
\text { and } \\
\text { mandibular } \\
\text { overdentur } \\
\text { es; } \\
\text { majority of } \\
\text { patients } \\
\text { having a }\end{array}$ & NR \\
\hline
\end{tabular}

Journal of Prosthodontics, Vol 25, No. S1 (January 2016): pg. S16-S31. DOI. This article is @ Wiley and permission has been granted for this version to appear in e-Publications@Marquette. Wiley does not grant permission for this article to be further copied/distributed or hosted elsewhere without the express permission from Wiley. 
NOT THE PUBLISHED VERSION; this is the author's final, peer-reviewed manuscript. The published version may be accessed by following the link in the citation at the bottom of the page.

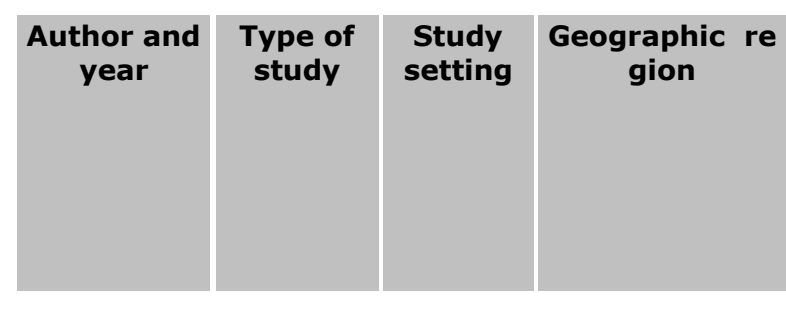

Sreenivasan RCT-

et al $(2010)^{14}$ doubleblinded
Communit Middle East y centers (Israel) in Israel

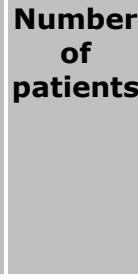

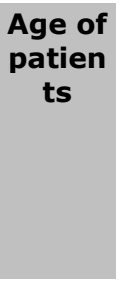

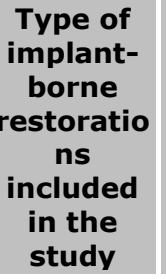

gold bar and a few having solitary ball anchors

120

Range: Implant75 crowns Palmolive years Company Mean age:

NR
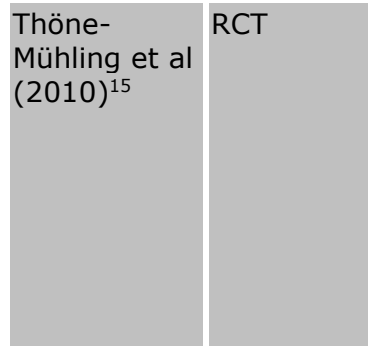

Kleis et al RCT $(2009)^{16}$

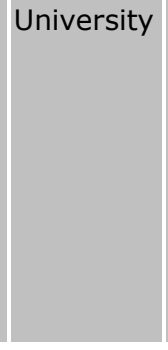

University Europe (Germany)

\section{(Germany)}

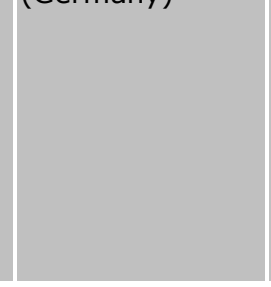

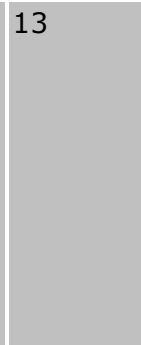

60
Study sponsors hip

\section{Implant- supported crowns, FDPs, and double crown retained overdentur abutments}

Implantsupported

Range:
37 to
67
years
Mean
age:
NR

Range:

46 to

95

years

Mean

age:

NR overdentur es in the mandible (with 3 types of attachment systems)

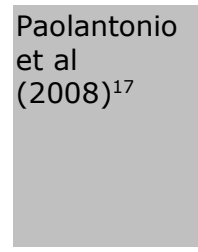

Ramberg et al $(2009)^{18}$

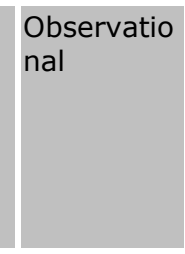

RCTdoubleblinded

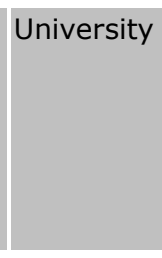

University Europe (Sweden and Italy)

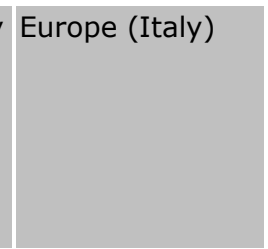

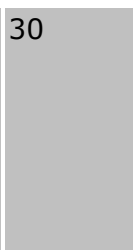

60

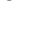

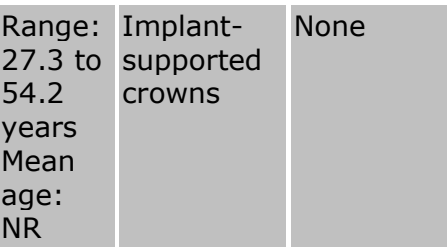

Range: Type of Colgate30 to implant Palmolive 70 restoration Company years was not Mean clarified age:

NR

Range: Implant- Product NR supported support by Mean crowns and Braun age: 56 FDP in the Oral-B maxillary

Journal of Prosthodontics, Vol 25, No. S1 (January 2016): pg. S16-S31. DOI. This article is @ W Wiley and permission has been granted for this version to appear in e-Publications@Marquette. Wiley does not grant permission for this article to be further copied/distributed or hosted elsewhere without the express permission from Wiley. 


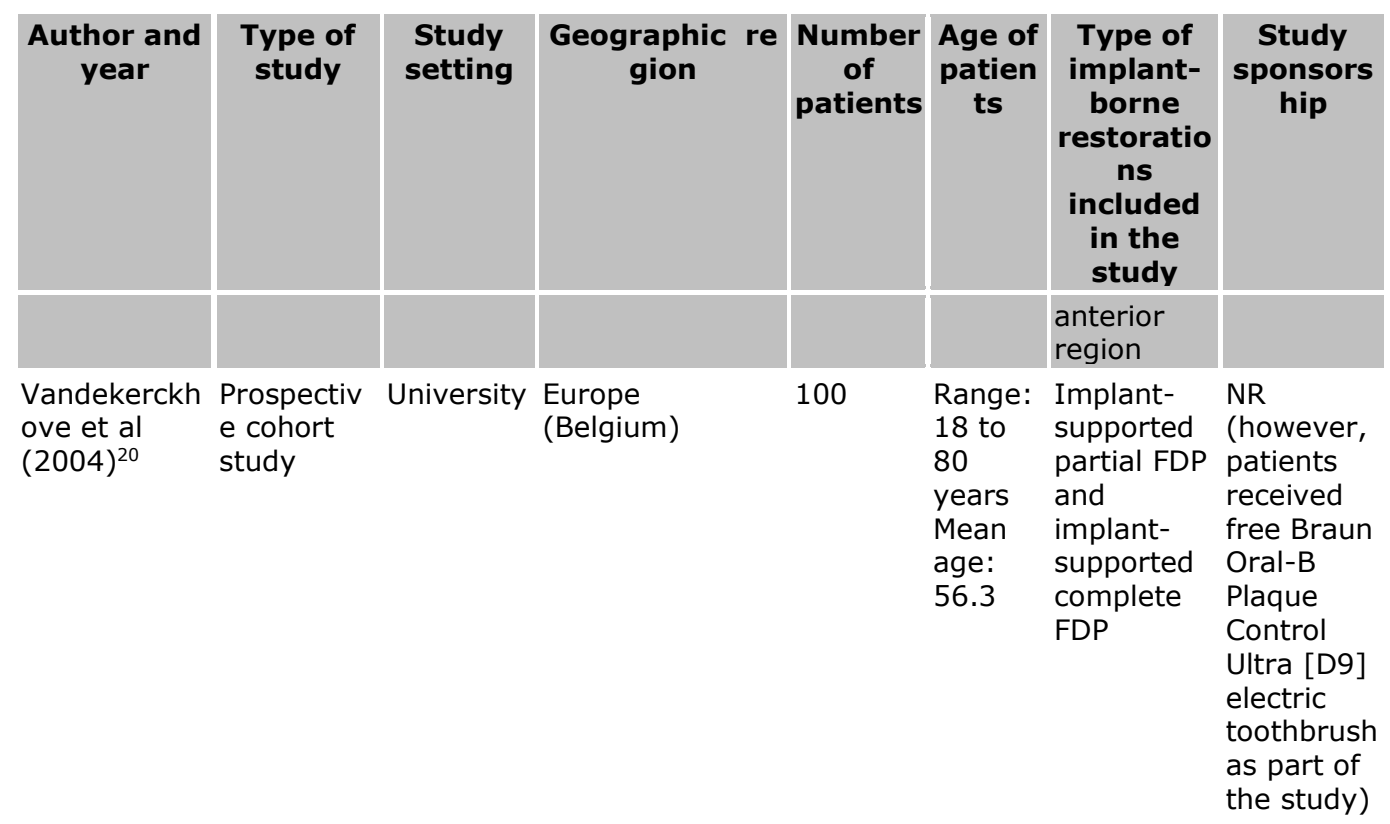

Out of the 20 studies, eleven were randomized controlled clinical trials (RCTs), and nine were observational studies. The majority of the studies $(15 / 20)$ were conducted in the past 5 years, and most studies were conducted in Europe (15), followed by Asia (2), South America (1), the United States (1), and the Middle East (1). A total of 1088 patients were included in these 20 studies. Fifteen studies were conducted exclusively in a university setting, two involved a university as well as a private practice setting, one was exclusive to private practice, and two were conducted in a community center or independent center. Eight studies received corporate support (partial or full), four were supported by university and/or government, three reported no support, and five did not report on study sponsorship.

To segregate the qualitative data and provide a meaningful method of understanding outcomes, the analyzed data were grouped into three categories: (1) outcomes related to patient-specific restorative treatment; (2) outcomes related to maintenance using oral topical agents and hygiene aids; and (3) outcomes related to maintenance using professional intervention. Additionally, the professional intervention was dichotomized as biological maintenance and mechanical maintenance (Table 3 ). 
NOT THE PUBLISHED VERSION; this is the author's final, peer-reviewed manuscript. The published version may be accessed by following the link in the citation at the bottom of the page.

Table 3. Professional maintenance, at-home maintenance, and patient recall data from the 20 included studies that reported on recall and maintenance of implant-borne restorations

\begin{tabular}{|c|c|c|c|c|c|}
$\begin{array}{c}\text { Author and } \\
\text { year }\end{array}$ & $\begin{array}{c}\text { Categorization } \\
\text { of study } \\
\text { outcome in } \\
\text { this systematic } \\
\text { review }\end{array}$ & $\begin{array}{c}\text { Primary } \\
\text { objective of } \\
\text { the study }\end{array}$ & $\begin{array}{c}\text { Professional } \\
\text { maintenance } \\
\text { regimen } \\
\text { reported in } \\
\text { the study }\end{array}$ & $\begin{array}{c}\text { At-home } \\
\text { maintenance } \\
\text { regimen } \\
\text { reported in the } \\
\text { study }\end{array}$ & $\begin{array}{c}\text { Patient } \\
\text { recall } \\
\text { regimen } \\
\text { used in the } \\
\text { study }\end{array}$ \\
\hline
\end{tabular}

1. PTFE: polytetrafluoroethylene; PEEK: polyetherether ketone; $\mathrm{CHX}$ : chlorhexidine.

\begin{abstract}
Magnuson et al Agent-related $(2013)^{1}$

outcome
\end{abstract}

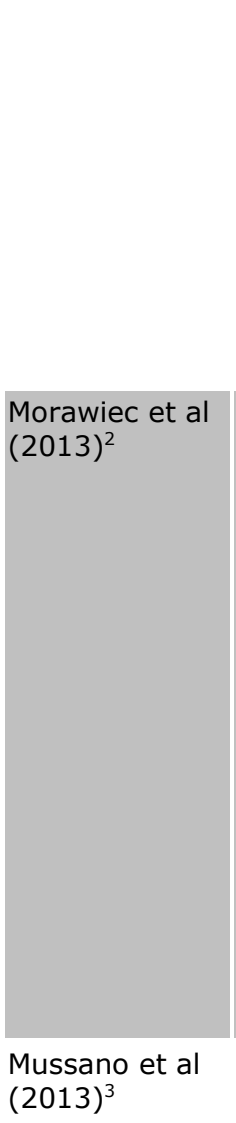

To determine NA
the
effectiveness
of water
flosser in
reducing the
bleeding on
probing
index, when
compared to
flossing, in
patients with
implant
crowns

To determine

the

effectiveness

of a

dentifrice-

containing

ethanol

extract of

Brazilian

green

propolis on

selected oral

health

parameters,

oral

microflora,

and

periodontal

health

Professional interventionrelated outcome

\section{To compare} the peri-

implant

outcomes on

mandibular

overdenture

patients,

when

professional

maintenance

was

performed by

using PTFE

curettes or a

glycine

powder air
Participants were asked to either use a string

flosser or a water

flosser in

conjunction with

manual brushing

(based on the

treatment arm assigned)

\section{NA}

Patients were instructed to either use a dentifrice containing 3\% ethanol extract of Brazilian propolis or a placebo dentifrice that did not have propolis

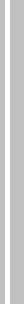

Patients were either assigned to professional cleaning with hand instrumentatio $n$ with PTFE curettes or a glycine powder air polishing

system

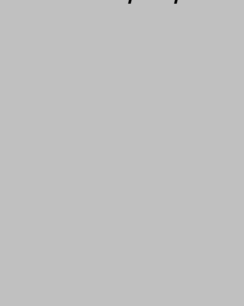

Not reported
1 hour after treatment, 1 week, and 4 weeks

14 , and 30

days

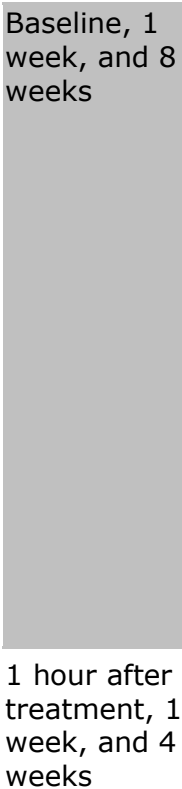

Baseline, 1 week, and 8 weeks

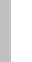


NOT THE PUBLISHED VERSION; this is the author's final, peer-reviewed manuscript. The published version may be accessed by following the link in the citation at the bottom of the page.

\begin{tabular}{|c|c|c|c|c|c|}
\hline $\begin{array}{c}\text { Author and } \\
\text { year }\end{array}$ & $\begin{array}{l}\text { Categorization } \\
\text { of study } \\
\text { outcome in } \\
\text { this systematic } \\
\text { review }\end{array}$ & $\begin{array}{l}\text { Primary } \\
\text { objective of } \\
\text { the study }\end{array}$ & $\begin{array}{l}\text { Professional } \\
\text { maintenance } \\
\text { regimen } \\
\text { reported in } \\
\text { the study }\end{array}$ & $\begin{array}{l}\text { At-home } \\
\text { maintenance } \\
\text { regimen } \\
\text { reported in the } \\
\text { study }\end{array}$ & $\begin{array}{l}\text { Patient } \\
\text { recall } \\
\text { regimen } \\
\text { used in the } \\
\text { study }\end{array}$ \\
\hline & & $\begin{array}{l}\text { polishing } \\
\text { system }\end{array}$ & & & \\
\hline $\begin{array}{l}\text { Swierkot et al } \\
(2013)^{4}\end{array}$ & $\begin{array}{l}\text { Agent-related } \\
\text { outcome }\end{array}$ & $\begin{array}{l}\text { To compare } \\
\text { plaque levels } \\
\text { following } \\
\text { sonic- } \\
\text { powered and } \\
\text { manual } \\
\text { toothbrushing } \\
\text { in subjects } \\
\text { with dental } \\
\text { implants }\end{array}$ & NA & $\begin{array}{l}\text { Participants were } \\
\text { asked to either } \\
\text { brush with manual } \\
\text { toothbrush or } \\
\text { sonic-powered } \\
\text { toothbrush using } \\
\text { the modified bass } \\
\text { technique (based } \\
\text { on the treatment } \\
\text { arm assigned) }\end{array}$ & $\begin{array}{l}\text { Baseline, 3, } \\
6,9, \text { and } 12 \\
\text { months }\end{array}$ \\
\hline $\begin{array}{l}\text { Zou et al } \\
(2013)^{5}\end{array}$ & $\begin{array}{l}\text { Patient/treatme } \\
\text { nt } \\
\text { characteristic- } \\
\text { related outcome }\end{array}$ & $\begin{array}{l}\text { To evaluate } \\
\text { telescopic } \\
\text { crown, bar, } \\
\text { and self- } \\
\text { aligning } \\
\text { attachments } \\
\text { used in } \\
\text { removable } \\
\text { four implant- } \\
\text { supported } \\
\text { overdentures } \\
\text { for patients } \\
\text { with } \\
\text { edentulous } \\
\text { maxilla }\end{array}$ & $\begin{array}{l}\text { Not specified, } \\
\text { but authors } \\
\text { stated that } \\
\text { biologic and } \\
\text { mechanical } \\
\text { professional } \\
\text { maintenance } \\
\text { procedures } \\
\text { were } \\
\text { performed at } \\
\text { baseline and } \\
\text { annually for } 3 \\
\text { years }\end{array}$ & Not reported & $\begin{array}{l}\text { Baseline and } \\
\text { follow-up } \\
\text { radiographs } \\
\text { were } \\
\text { obtained 12, } \\
24 \text {, and } 36 \\
\text { months after } \\
\text { functional } \\
\text { loading } \\
\text { Patient } \\
\text { satisfaction } \\
\text { was } \\
\text { completed } \\
\text { at end of 3- } \\
\text { year } \\
\text { evaluation }\end{array}$ \\
\hline $\begin{array}{l}\text { De Siena et al } \\
(2012)^{6}\end{array}$ & $\begin{array}{l}\text { Agent-related } \\
\text { outcome as well } \\
\text { as professional } \\
\text { intervention- } \\
\text { related outcome }\end{array}$ & $\begin{array}{l}\text { To compare } \\
\text { the use of } \\
\text { two CHX- } \\
\text { based } \\
\text { antimicrobial } \\
\text { agents as an } \\
\text { adjunct to } \\
\text { mechanical } \\
\text { therapy for } \\
\text { the treatment } \\
\text { of peri- } \\
\text { implant } \\
\text { mucositis }\end{array}$ & $\begin{array}{l}\text { Professional } \\
\text { cleaning was } \\
\text { performed by } \\
\text { a single } \\
\text { experienced } \\
\text { dental } \\
\text { hygienist for } \\
\text { all patients; } \\
\text { patients were } \\
\text { then } \\
\text { prescribed } \\
\text { CHX agent }\end{array}$ & $\begin{array}{l}\text { Patients were } \\
\text { asked not to } \\
\text { modify their } \\
\text { normal oral } \\
\text { hygiene measures } \\
\text { but asked to } \\
\text { supplement by } \\
\text { using either CHX } \\
0.2 \% \text { mouthwash } \\
\text { or chlorhexidne } \\
1 \% \text { gel (based on } \\
\text { the treatment arm } \\
\text { assigned) }\end{array}$ & $\begin{array}{l}\text { Baseline, } 10 \\
\text { days, } 1 \\
\text { month, and } \\
3 \text { months }\end{array}$ \\
\hline $\begin{array}{l}\text { Chongcharoen } \\
\text { et al }(2011)^{7}\end{array}$ & $\begin{array}{l}\text { Agent-related } \\
\text { outcome }\end{array}$ & $\begin{array}{l}\text { To compare } \\
\text { the } \\
\text { interproximal } \\
\text { cleaning } \\
\text { efficacy of a } \\
\text { specially } \\
\text { designed } \\
\text { interproximal } \\
\text { brush with a } \\
5 \text { mm } \\
\text { diameter } \\
\text { (with a } \\
\text { conventional } \\
\text { interproximal } \\
\text { brush with a }\end{array}$ & $\begin{array}{l}\text { In this } \\
\text { experiment, } \\
\text { patients were } \\
\text { asked to not } \\
\text { brush for } 3 \\
\text { days followed } \\
\text { by second } \\
\text { appointment } \\
\text { where an } \\
\text { assistant } \\
\text { guided the } \\
\text { interdental } \\
\text { brush through } \\
\text { the contacts } \\
\text { three times }\end{array}$ & Not reported & $\begin{array}{l}\text { Baseline, } 3 \\
\text { days, } 6 \text { days }\end{array}$ \\
\hline
\end{tabular}

Journal of Prosthodontics, Vol 25, No. S1 (January 2016): pg. S16-S31. DOI. This article is (C) Wiley and permission has been granted for this version to appear in e-Publications@Marquette. Wiley does not grant permission for this article to be further copied/distributed or hosted elsewhere without the express permission from Wiley. 
NOT THE PUBLISHED VERSION; this is the author's final, peer-reviewed manuscript. The published version may be accessed by following the link in the citation at the bottom of the page.

\begin{tabular}{|c|c|c|c|c|c|}
\hline $\begin{array}{c}\text { Author and } \\
\text { year }\end{array}$ & $\begin{array}{c}\text { Categorization } \\
\text { of study } \\
\text { outcome in } \\
\text { this systematic } \\
\text { review }\end{array}$ & $\begin{array}{c}\text { Primary } \\
\text { objective of } \\
\text { the study }\end{array}$ & $\begin{array}{l}\text { Professional } \\
\text { maintenance } \\
\text { regimen } \\
\text { reported in } \\
\text { the study }\end{array}$ & $\begin{array}{l}\text { At-home } \\
\text { maintenance } \\
\text { regimen } \\
\text { reported in the } \\
\text { study }\end{array}$ & $\begin{array}{l}\text { Patient } \\
\text { recall } \\
\text { regimen } \\
\text { used in the } \\
\text { study }\end{array}$ \\
\hline & & $\begin{array}{l}3 \mathrm{~mm} \\
\text { diameter }\end{array}$ & $\begin{array}{l}\text { and process } \\
\text { was repeated } \\
\text { with the other } \\
\text { brush after } 3 \\
\text { more days of } \\
\text { abolishing } \\
\text { toothbrushing }\end{array}$ & & \\
\hline $\begin{array}{l}\text { Costa et al } \\
(2011)^{8}\end{array}$ & $\begin{array}{l}\text { Professional } \\
\text { intervention- } \\
\text { related outcome }\end{array}$ & $\begin{array}{l}\text { To determine } \\
\text { among } \\
\text { patients with } \\
\text { peri-implant } \\
\text { mucositis, } \\
\text { whether a } \\
\text { professional } \\
\text { maintenance } \\
\text { program } \\
\text { resulted in a } \\
\text { more } \\
\text { favorable } \\
\text { outcome } \\
\text { compared to } \\
\text { patients who } \\
\text { did not } \\
\text { receive } \\
\text { professional } \\
\text { maintenance }\end{array}$ & $\begin{array}{l}\text { Three } \\
\text { procedures } \\
\text { were } \\
\text { performed: (1) } \\
\text { periodontal } \\
\text { and peri- } \\
\text { implant status } \\
\text { assessment; } \\
\text { (2) the } \\
\text { application of } \\
\text { disclosing } \\
\text { agents and } \\
\text { oral hygiene } \\
\text { instructions; } \\
\text { (3) coronal } \\
\text { prophylaxis } \\
\text { and } \\
\text { mechanical } \\
\text { debridement, } \\
\text { when } \\
\text { necessary }\end{array}$ & Not reported & $\begin{array}{l}\text { This was a } \\
\text { retrospectiv } \\
\text { e study, } \\
\text { which } \\
\text { evaluated } \\
\text { the effect of } \\
\text { patients } \\
\text { returning for } \\
\text { professional } \\
\text { maintenance } \\
\text { vs. patients } \\
\text { who did not. } \\
\text { Patients } \\
\text { returning to } \\
\text { professional } \\
\text { maintenance } \\
\text { had an } \\
\text { average of } \\
5.6 \text { visits } \\
\text { during the } \\
5 \text {-year } \\
\text { maintenance } \\
\text { period }\end{array}$ \\
\hline $\begin{array}{l}\text { Fischer et al } \\
(2011)^{9}\end{array}$ & $\begin{array}{l}\text { Patient/treatme } \\
\text { nt } \\
\text { characteristic- } \\
\text { related outcome }\end{array}$ & $\begin{array}{l}\text { To evaluate } \\
\text { and report } \\
10 \text {-year data } \\
\text { on outcomes } \\
\text { and } \\
\text { maintenance } \\
\text { of screw- } \\
\text { retained } \\
\text { implant- } \\
\text { supported } \\
\text { full-arch } \\
\text { casted } \\
\text { titanium-resin } \\
\text { prostheses in } \\
\text { the } \\
\text { edentulous } \\
\text { maxilla }\end{array}$ & $\begin{array}{l}\text { Not specified, } \\
\text { but authors } \\
\text { stated that } \\
\text { professional } \\
\text { maintenance } \\
\text { procedures } \\
\text { were } \\
\text { performed at } \\
\text { baseline and } \\
\text { at } 1,3,5 \text {, and } \\
\text { at } 10 \text { years }\end{array}$ & Not reported & $\begin{array}{l}\text { Baseline and } \\
1-, 3-, 5- \\
10-\text { year } \\
\text { follow-up }\end{array}$ \\
\hline $\begin{array}{l}\text { Katsoulis et al } \\
(2011)^{10}\end{array}$ & $\begin{array}{l}\text { Patient/treatme } \\
\text { nt } \\
\text { characteristic- } \\
\text { related outcome }\end{array}$ & $\begin{array}{l}\text { To analyze } \\
\text { professional } \\
\text { maintenance } \\
\text { of fixed } \\
\text { maxillary } \\
\text { prostheses } \\
\text { and } \\
\text { overdentures } \\
\text { based on }\end{array}$ & $\begin{array}{l}\text { Professional } \\
\text { cleaning, oral } \\
\text { hygiene } \\
\text { instructions, } \\
\text { evaluation of } \\
\text { prosthetic } \\
\text { mechanical } \\
\text { maintenance }\end{array}$ & Not reported & Twice a year \\
\hline
\end{tabular}

Journal of Prosthodontics, Vol 25, No. S1 (January 2016): pg. S16-S31. DOI. This article is (C) Wiley and permission has been granted for this version to appear in e-Publications@Marquette. Wiley does not grant permission for this article to be further copied/distributed or hosted elsewhere without the express permission from Wiley. 
NOT THE PUBLISHED VERSION; this is the author's final, peer-reviewed manuscript. The published version may be accessed by following the link in the citation at the bottom of the page.

\begin{tabular}{|c|c|c|c|c|c|}
\hline $\begin{array}{c}\text { Author and } \\
\text { year }\end{array}$ & $\begin{array}{l}\text { Categorization } \\
\text { of study } \\
\text { outcome in } \\
\text { this systematic } \\
\text { review }\end{array}$ & $\begin{array}{c}\text { Primary } \\
\text { objective of } \\
\text { the study }\end{array}$ & $\begin{array}{l}\text { Professional } \\
\text { maintenance } \\
\text { regimen } \\
\text { reported in } \\
\text { the study }\end{array}$ & $\begin{array}{l}\text { At-home } \\
\text { maintenance } \\
\text { regimen } \\
\text { reported in the } \\
\text { study }\end{array}$ & $\begin{array}{l}\text { Patient } \\
\text { recall } \\
\text { regimen } \\
\text { used in the } \\
\text { study }\end{array}$ \\
\hline & & $\begin{array}{l}\text { conventional } \\
\text { gold bars or } \\
\text { titanium bars } \\
\text { and } \\
\text { frameworks } \\
\text { fabricated } \\
\text { with } \\
\text { CAD/CAM } \\
\text { technology }\end{array}$ & $\begin{array}{l}\text { events and } \\
\text { needs }\end{array}$ & & \\
\hline $\begin{array}{l}\text { Akça et al } \\
(2010)^{11}\end{array}$ & $\begin{array}{l}\text { Patient/treatme } \\
\text { nt } \\
\text { characteristic- } \\
\text { related outcome }\end{array}$ & $\begin{array}{l}\text { To evaluate } \\
\text { peri-implant } \\
\text { parameters } \\
\text { and } \\
\text { professional } \\
\text { mechanical } \\
\text { maintenance } \\
\text { outcomes of } \\
\text { patients with } \\
\text { bar-retained } \\
\text { implant- } \\
\text { supported } \\
\text { overdentures }\end{array}$ & $\begin{array}{l}\text { Not specified, } \\
\text { but authors } \\
\text { stated that } \\
\text { professional } \\
\text { maintenance } \\
\text { procedures } \\
\text { were } \\
\text { performed } \\
\text { annually }\end{array}$ & Not reported & Annual \\
\hline $\begin{array}{l}\text { Corbella et al } \\
(2010)^{12}\end{array}$ & $\begin{array}{l}\text { Professional } \\
\text { intervention- } \\
\text { related outcome }\end{array}$ & $\begin{array}{l}\text { To assess the } \\
\text { outcomes of } \\
\text { an implant } \\
\text { maintenance } \\
\text { protocol for } \\
\text { implants } \\
\text { supporting a } \\
\text { full-arch } \\
\text { rehabilitation }\end{array}$ & $\begin{array}{l}\text { Professional } \\
\text { maintenance } \\
\text { with manual } \\
\text { PTFE curettes, } \\
\text { electric } \\
\text { toothbrushes, } \\
\text { and } \\
\text { interdental } \\
\text { floss for } \\
\text { removal of } \\
\text { plaque }\end{array}$ & $\begin{array}{l}\text { A very specific } \\
\text { protocol that } \\
\text { included CHX } \\
0.2 \% \text { rinse, } 3 \\
\text { days before and } 7 \\
\text { days after } \\
\text { surgery, the use } \\
\text { of soft toothbrush } \\
\text { on prosthetic } \\
\text { surfaces with } \\
\text { prosthetic } \\
\text { restoration, the } \\
\text { additional use of } \\
\text { small or medium } \\
\text { diameter brushes } \\
2 \text { weeks after } \\
\text { surgery, and } \\
\text { toothbrushes, } \\
\text { interdental } \\
\text { brushes, and } \\
\text { interdental floss } \\
\text { after definitive } \\
\text { restoration }\end{array}$ & $\begin{array}{l}\text { Baseline and } \\
\text { then every } 6 \\
\text { months for } 2 \\
\text { years and } \\
\text { then yearly } \\
\text { for up to } 4 \\
\text { years }\end{array}$ \\
\hline $\begin{array}{l}\text { Rentsch-Kollar } \\
\text { et al }(2010)^{13}\end{array}$ & $\begin{array}{l}\text { Professional } \\
\text { intervention- } \\
\text { related outcome }\end{array}$ & $\begin{array}{l}\text { To analyze } \\
\text { patient } \\
\text { compliance } \\
\text { and } \\
\text { prosthetic } \\
\text { maintenance } \\
\text { service, } \\
\text { including } \\
\text { complications } \\
\text { with the } \\
\text { retention }\end{array}$ & $\begin{array}{l}\text { Professional } \\
\text { mechanical } \\
\text { maintenance } \\
\text { included } \\
\text { replacement of } \\
\text { loose, broken, } \\
\text { and lost } \\
\text { matrices or } \\
\text { repair and } \\
\text { remaking the } \\
\text { prosthesis }\end{array}$ & Not reported & Twice a year \\
\hline
\end{tabular}

Journal of Prosthodontics, Vol 25, No. S1 (January 2016): pg. S16-S31. DOI. This article is (C) Wiley and permission has been granted for this version to appear in e-Publications@Marquette. Wiley does not grant permission for this article to be further copied/distributed or hosted elsewhere without the express permission from Wiley. 
NOT THE PUBLISHED VERSION; this is the author's final, peer-reviewed manuscript. The published version may be accessed by following the link in the citation at the bottom of the page.

\begin{tabular}{|c|c|c|c|c|c|}
\hline $\begin{array}{c}\text { Author and } \\
\text { year }\end{array}$ & $\begin{array}{c}\text { Categorization } \\
\text { of study } \\
\text { outcome in } \\
\text { this systematic } \\
\text { review }\end{array}$ & $\begin{array}{l}\text { Primary } \\
\text { objective of } \\
\text { the study }\end{array}$ & $\begin{array}{l}\text { Professional } \\
\text { maintenance } \\
\text { regimen } \\
\text { reported in } \\
\text { the study }\end{array}$ & $\begin{array}{l}\text { At-home } \\
\text { maintenance } \\
\text { regimen } \\
\text { reported in the } \\
\text { study }\end{array}$ & $\begin{array}{l}\text { Patient } \\
\text { recall } \\
\text { regimen } \\
\text { used in the } \\
\text { study }\end{array}$ \\
\hline & & $\begin{array}{l}\text { components } \\
\text { of mandibular } \\
\text { overdentures }\end{array}$ & & & \\
\hline $\begin{array}{l}\text { Sreenivasan et } \\
\text { al }(2010)^{14}\end{array}$ & $\begin{array}{l}\text { Agent-related } \\
\text { outcome }\end{array}$ & $\begin{array}{l}\text { To determine } \\
\text { the effect of a } \\
0.3 \% \\
\text { triclosan } / 2 \% \\
\text { copolymer } \\
\text { dentifrice on } \\
\text { oral biofilms } \\
\text { and gingival } \\
\text { inflammation } \\
\text { on dental } \\
\text { implants and } \\
\text { peri-implant } \\
\text { tissues }\end{array}$ & Not reported & $\begin{array}{l}\text { Participants were } \\
\text { asked to either } \\
\text { brush twice daily } \\
\text { with dentifrice } \\
\text { containing } 0.3 \% \\
\text { triclosan/copolym } \\
\text { er dentifrice or a } \\
\text { dentrifrice without } \\
\text { triclosan for } 6 \\
\text { months }\end{array}$ & $\begin{array}{l}\text { Baseline, } 3 \\
\text { and } 6 \\
\text { months }\end{array}$ \\
\hline $\begin{array}{l}\text { Thöne-Mühling } \\
\text { et al }(2010)^{15}\end{array}$ & $\begin{array}{l}\text { Agent-related } \\
\text { outcome as well } \\
\text { as professional } \\
\text { intervention- } \\
\text { related outcome }\end{array}$ & $\begin{array}{l}\text { To determine } \\
\text { if an } \\
\text { additional full } \\
\text { mouth } \\
\text { disinfection } \\
\text { with CHX } \\
\text { results in a } \\
\text { greater } \\
\text { clinical and } \\
\text { microbiologic } \\
\text { al } \\
\text { improvement } \\
\text { compared } \\
\text { with sole } \\
\text { mechanical } \\
\text { debridement, } \\
\text { within one } \\
\text { session in } \\
\text { patients with } \\
\text { peri-implant } \\
\text { mucositis and } \\
\text { treated } \\
\text { chronic } \\
\text { periodontitis }\end{array}$ & $\begin{array}{l}\text { Professional } \\
\text { maintenance } \\
\text { for implants } \\
\text { included use of } \\
\text { plastic scalers } \\
\text { and PEEK- } \\
\text { coated } \\
\text { ultrasonic } \\
\text { instruments. } \\
\text { In the test } \\
\text { group, } \\
\text { additionally, } \\
\text { CHX gel } 1 \% \\
\text { was applied } \\
\text { once } \\
\text { subgingivally, } \\
\text { and the } \\
\text { dorsum of the } \\
\text { tongue was } \\
\text { brushed for } 1 \\
\text { min with a } 1 \% \\
\text { CHX gel, and } \\
\text { each tonsil } \\
\text { was sprayed } \\
\text { four times with } \\
0.2 \% \text { CHX } \\
\text { spray }\end{array}$ & $\begin{array}{l}\text { In the test group, } \\
\text { in addition to the } \\
\text { professionally } \\
\text { applied } \mathrm{CHX} \text {, } \\
\text { patients were } \\
\text { instructed to rinse } \\
\text { twice for } 1 \mathrm{~min} \\
\text { with } 0.2 \% \mathrm{CHX} \text {. } \\
\text { For } 14 \text { days after } \\
\text { the treatment, } \\
\text { patients were } \\
\text { instructed to rinse } \\
\text { once daily for } 30 \\
\text { sec with } 0.2 \% \\
\mathrm{CHX} \text { solution and } \\
\text { also to spray the } \\
\text { tonsils once daily } \\
\text { with } 0.2 \% \mathrm{CHX} \\
\text { spray }\end{array}$ & $\begin{array}{l}\text { Baseline, } 1 \\
\text { month, 2, 4, } \\
8 \text { months }\end{array}$ \\
\hline $\begin{array}{l}\text { Kleis et al } \\
(2009)^{16}\end{array}$ & $\begin{array}{l}\text { Patient/treatme } \\
\text { nt } \\
\text { characteristic- } \\
\text { related outcome }\end{array}$ & $\begin{array}{l}\text { To study the } \\
\text { prosthodontic } \\
\text { maintenance } \\
\text { of } 2 \text {-implant } \\
\text { overdentures } \\
\text { with self- } \\
\text { aligning } \\
\text { attachment } \\
\text { system } \\
\text { (Locator) } \\
\text { attachment } \\
\text { compared to } \\
\text { two different }\end{array}$ & $\begin{array}{l}\text { Not specified, } \\
\text { but authors } \\
\text { stated that } \\
\text { professional } \\
\text { mechanical } \\
\text { maintenance } \\
\text { procedures } \\
\text { were } \\
\text { performed as } \\
\text { needed and at } \\
12 \text { months }\end{array}$ & Not reported & $\begin{array}{l}\text { Baseline, as } \\
\text { needed for } \\
\text { maintenance } \\
\text {, and at } 12 \\
\text { months }\end{array}$ \\
\hline
\end{tabular}

Journal of Prosthodontics, Vol 25, No. S1 (January 2016): pg. S16-S31. DOI. This article is @ Wiley and permission has been granted for this version to appear in e-Publications@Marquette. Wiley does not grant permission for this article to be further copied/distributed or hosted elsewhere without the express permission from Wiley. 
NOT THE PUBLISHED VERSION; this is the author's final, peer-reviewed manuscript. The published version may be accessed by following the link in the citation at the bottom of the page.

\begin{tabular}{|c|c|c|c|c|c|}
\hline $\begin{array}{c}\text { Author and } \\
\text { year }\end{array}$ & $\begin{array}{c}\text { Categorization } \\
\text { of study } \\
\text { outcome in } \\
\text { this systematic } \\
\text { review }\end{array}$ & $\begin{array}{c}\text { Primary } \\
\text { objective of } \\
\text { the study }\end{array}$ & $\begin{array}{l}\text { Professional } \\
\text { maintenance } \\
\text { regimen } \\
\text { reported in } \\
\text { the study }\end{array}$ & $\begin{array}{l}\text { At-home } \\
\text { maintenance } \\
\text { regimen } \\
\text { reported in the } \\
\text { study }\end{array}$ & $\begin{array}{l}\text { Patient } \\
\text { recall } \\
\text { regimen } \\
\text { used in the } \\
\text { study }\end{array}$ \\
\hline & & $\begin{array}{l}\text { ball } \\
\text { attachment } \\
\text { systems }\end{array}$ & & & \\
\hline $\begin{array}{l}\text { Paolantonio et } \\
\text { al }(2008)^{17}\end{array}$ & $\begin{array}{l}\text { Agent-related } \\
\text { outcome }\end{array}$ & $\begin{array}{l}\text { To evaluate } \\
\text { the } \\
\text { effectiveness } \\
\text { of a } 1 \% \mathrm{CHX} \\
\text { gel on the } \\
\text { internal } \\
\text { bacterial } \\
\text { contaminatio } \\
\mathrm{n} \text { of implants } \\
\text { with screw- } \\
\text { retained } \\
\text { abutments }\end{array}$ & $\begin{array}{l}\text { Not specified, } \\
\text { but authors } \\
\text { stated that } \\
\text { professional } \\
\text { biological } \\
\text { maintenance } \\
\text { was performed } \\
\text { at baseline } \\
\text { The } 1 \% \mathrm{CHX} \\
\text { gel was placed } \\
\text { inside the } \\
\text { implant at the } \\
\text { 3-month recall } \\
\text { in the test } \\
\text { group }\end{array}$ & Not reported & $\begin{array}{l}\text { Baseline, } 3 \\
\text { and } 6 \\
\text { months }\end{array}$ \\
\hline $\begin{array}{l}\text { Ramberg et al } \\
(2009)^{18}\end{array}$ & $\begin{array}{l}\text { Agent-related } \\
\text { outcome }\end{array}$ & $\begin{array}{l}\text { To determine } \\
\text { the effect of a } \\
\text { dentifrice } \\
\text { with } 0.3 \% \\
\text { triclosan on } \\
\text { peri-implant } \\
\text { mucositis in } \\
\text { subjects } \\
\text { restored with } \\
\text { dental } \\
\text { implants }\end{array}$ & $\begin{array}{l}\text { Only oral } \\
\text { hygiene } \\
\text { instructions } \\
\text { were given to } \\
\text { all patients }\end{array}$ & $\begin{array}{l}\text { Participants were } \\
\text { asked to either } \\
\text { brush twice daily } \\
\text { with dentifrice } \\
\text { containing } 0.3 \% \\
\text { triclosan/copolym } \\
\text { er dentifrice or a } \\
\text { dentrifrice } \\
0.243 \% \text { sodium } \\
\text { fluoride in a silica } \\
\text { base for } 6 \text { months }\end{array}$ & $\begin{array}{l}\text { Baseline, } 3 \\
\text { and } 6 \\
\text { months }\end{array}$ \\
\hline $\begin{array}{l}\text { Rasperini et al } \\
(2008)^{19}\end{array}$ & $\begin{array}{l}\text { Agent-related } \\
\text { outcome }\end{array}$ & $\begin{array}{l}\text { To evaluate } \\
\text { the safety } \\
\text { and the } \\
\text { acceptability } \\
\text { of an electric } \\
\text { toothbrush } \\
\text { used on the } \\
\text { peri-implant } \\
\text { mucosa of } \\
\text { implants } \\
\text { placed in the } \\
\text { esthetic } \\
\text { region }\end{array}$ & Not reported & $\begin{array}{l}\text { Patients were } \\
\text { instructed to use } \\
\text { the electric } \\
\text { toothbrush to } \\
\text { brush twice a day } \\
\text { over a } 12-\text { month } \\
\text { period }\end{array}$ & $\begin{array}{l}\text { Baseline, 3, } \\
6 \text {, and } 12 \\
\text { months }\end{array}$ \\
\hline $\begin{array}{l}\text { Vandekerckhov } \\
\text { e et al }(2004)^{20}\end{array}$ & $\begin{array}{l}\text { Agent-related } \\
\text { outcome }\end{array}$ & $\begin{array}{l}\text { To evaluate } \\
\text { the safety, } \\
\text { efficacy, and } \\
\text { acceptability } \\
\text { of an electric } \\
\text { toothbrush in } \\
\text { patients } \\
\text { rehabilitated } \\
\text { with fixed } \\
\text { prostheses on } \\
\text { implants }\end{array}$ & Not reported & $\begin{array}{l}\text { Patients were } \\
\text { instructed to use } \\
\text { an electric } \\
\text { toothbrush to } \\
\text { brush twice a day. } \\
\text { They were } \\
\text { instructed to } \\
\text { adhere to their } \\
\text { normal interdental } \\
\text { cleaning } \\
\text { procedures, which } \\
\text { mostly consisted } \\
\text { of the use of }\end{array}$ & $\begin{array}{l}\text { Baseline, } \\
\text { month } 3,6, \\
\text { and } 12 \\
\text { months }\end{array}$ \\
\hline
\end{tabular}

Journal of Prosthodontics, Vol 25, No. S1 (January 2016): pg. S16-S31. DOI. This article is (C) Wiley and permission has been granted for this version to appear in e-Publications@Marquette. Wiley does not grant permission for this article to be further copied/distributed or hosted elsewhere without the express permission from Wiley. 
NOT THE PUBLISHED VERSION; this is the author's final, peer-reviewed manuscript. The published version may be accessed by following the link in the citation at the bottom of the page.

\begin{tabular}{|c|c|c|c|c|c|}
$\begin{array}{c}\text { Author and } \\
\text { year }\end{array}$ & $\begin{array}{c}\text { Categorization } \\
\text { of study } \\
\text { outcome in } \\
\text { this systematic } \\
\text { review }\end{array}$ & $\begin{array}{c}\text { Primary } \\
\text { objective of } \\
\text { the study }\end{array}$ & $\begin{array}{c}\text { Professional } \\
\text { maintenance } \\
\text { regimen } \\
\text { reported in } \\
\text { the study }\end{array}$ & $\begin{array}{c}\text { At-home } \\
\text { maintenance } \\
\text { regimen } \\
\text { reported in the } \\
\text { study }\end{array}$ & $\begin{array}{c}\text { Patient } \\
\text { recall } \\
\text { regimen } \\
\text { used in the } \\
\text { study }\end{array}$ \\
\hline & & & $\begin{array}{l}\text { interdental } \\
\text { brushes and } \\
\text { interdental floss }\end{array}$ \\
\hline
\end{tabular}

\section{Outcomes related to patient-specific restorative treatment}

Five studies ( 2 RCTs, 3 observational studies) reported on a specific patient/treatment characteristic-related improvement for professional and/or homecare maintenance of implant-borne restorations. Katsoulis et al, ${ }^{10}$ in a prospective study on 41 patients with maxillary removable or fixed rehabilitations, showed that cast bar overdentures, CAD/CAM milled bar overdentures, and fixed prostheses all resulted in professional maintenance during the 2-year study period, with the probability of a complication occurring in the first year being 60 to $70 \%$. Fewer maintenance issues were seen in implantsupported fixed restorations than in patients with a bar overdenture over a 2-year period. Fischer et al, ${ }^{9}$ in a prospective cohort study based on a larger RCT, collected data over a 10-year period on outcomes and maintenance of screw-retained implant-supported complete-arch cast titanium-acrylic resin prostheses in the edentulous maxilla of 24 patients. They evaluated the number of prosthetic teeth re-cemented or replaced, screw loosening, and the number of remakes of fixed prostheses, as well as cantilever length as a potential risk for fracture at baseline and 1-, 3-, 5-, and 10-year professional recall visits. They concluded that the most frequent complication was related to fractured denture teeth. The status of the opposing dentition and length of cantilever did not contribute to increased risk.

Akça et al ${ }^{11}$ conducted a prospective study on 35 patients with maxillary and mandibular bar-supported overdentures to compare prosthetic maintenance outcomes. They recorded data obtained at annual professional recall visits over a 5 -year period and concluded that mandibular bar-retained overdentures experienced a more frequent need for retightening of the retainer and occlusal adjustments than maxillary bar-retained overdentures. In an RCT of 60 patients, Kleis et $\mathrm{al}^{16}$ compared the prosthodontic maintenance of a self-aligning

Journal of Prosthodontics, Vol 25, No. S1 (January 2016): pg. S16-S31. DOI. This article is @ Wiley and permission has been granted for this version to appear in e-Publications@Marquette. Wiley does not grant permission for this article to be further copied/distributed or hosted elsewhere without the express permission from Wiley. 
attachment system (Locator system; Zest Anchors; Escondido, CA) to two traditional ball attachment systems in mandibular implant overdenture patients. They performed all professional mechanical maintenance as needed by patients and counted the number of professional maintenance visits. They concluded at the end of the 1year study that professional maintenance was restricted to loss of retention for all systems, but the self-aligning attachment system showed a higher rate of maintenance than the ball attachment systems. In contrast, Zou et $\mathrm{al}^{5}$ compared peri-implant health and professional maintenance in patients with either telescopic crowns, bar, or Locator attachments used in removable four implant-supported maxillary overdentures on 30 patients. Biologic and mechanical professional maintenance procedures were performed at baseline and annually for 3 years. The authors also counted the number of professional maintenance visits for each type of prosthesis. After a 3year period, the authors concluded that the Locator system produced superior clinical results compared to the telescopic crown and bar attachments in terms of peri-implant hygiene parameters, the frequency of prosthodontic maintenance measures, cost, and ease of denture fabrication.

\section{Outcomes related to maintenance using oral topical agents and oral hygiene aids}

Eleven studies (8 RCTs, 3 observational studies) reported on a specific agent-related improvement for professional and/or homecare maintenance of implant-borne restorations. In independent studies, Swierkot et al, ${ }^{4}$ Rasperini et al, ${ }^{19}$ and Vandekerckhove et al ${ }^{20}$ showed that the use of electric toothbrushes was a safe and efficient method of plaque removal around implant-borne restorations and had no adverse effects on peri-implant health; however, the superiority of electric toothbrushes over conventional toothbrushes was not proven in any of these studies. In a small-sample, double-blind RCT on eight patients, Chongcharoen et al ${ }^{7}$ compared a specially designed interproximal brush with a $5 \mathrm{~mm}$ diameter (Circum Brush; Top Cardent, Zurich, Switzerland) with a conventional interproximal brush with a $3 \mathrm{~mm}$ diameter in patients with implant-borne restorations (and natural teeth). The authors concluded that the specially designed

Journal of Prosthodontics, Vol 25, No. S1 (January 2016): pg. S16-S31. DOI. This article is @ Wiley and permission has been granted for this version to appear in e-Publications@Marquette. Wiley does not grant permission for this article to be further copied/distributed or hosted elsewhere without the express permission from Wiley. 
interproximal brush resulted in improved removal of plaque compared to the conventional interproximal brush.

Sreenivasan et al, ${ }^{14}$ in a double-blind RCT on 120 patients with at least one implant restoration, compared periodontal outcomes (including dental plaque, gingival index, and bleeding on probing) and bacterial outcomes in patients using a dentifrice with $0.3 \%$ triclosan/copolymer compared to patients using a dentifrice without triclosan. Assessments were performed at baseline, 3 months, and 6 months, and they showed that the dentifrice with $0.3 \%$ triclosan/copolymer was significantly more effective than a dentifrice without triclosan in improving periodontal and microbial outcomes. Similarly, a second double-blind RCT on 60 patients with various types of implant restorations by Ramberg et al ${ }^{18}$ investigated whether the use of a dentifrice containing $0.3 \%$ triclosan in a sodium fluoride silica base was more effective than a $0.243 \%$ sodium fluoride in a silica base on peri-implant mucositis. The outcomes measured were dental plaque, bleeding on probing, and periodontal probing depth. The authors showed that the dentifrice with $0.3 \%$ triclosan/copolymer was significantly more effective than a dentifrice without triclosan in improving peri-implant outcomes in patients with peri-implant mucositis. In another RCT on 16 patients with various types of implant restorations, Morawiec et $\mathrm{al}^{2}$ compared the use of a dentifrice containing ethanol extract of Brazilian green propolis with a placebo dentifrice without the propolis on selected oral health parameters, oral microflora, and periodontal health. The authors showed that over an 8week period, the use of propolis-containing dentifrice seemed to have a beneficial effect on peri-implant tissues and plaque accumulation, resulting in improved scores in approximal plaque index, oral hygiene index-debris component, and bleeding on probing.

De Siena et al, ${ }^{6}$ in an RCT on 30 patients, compared periodontal probing depth, plaque index, and bleeding index at 10 days, 1 month, and 3 months with patients using either a $0.2 \%$ chlorhexidine mouthrinse or a $1 \%$ chlorhexidine gel. Twenty-three patients completed the study, and patients had a complete arch reconstruction supported by four implants placed either in the intraforaminal region in the mandible or in the anterior maxilla with distal cantilever extensions. All prostheses were made of acrylic resin with a titanium structure and were screw-retained to implant abutments. Professional

Journal of Prosthodontics, Vol 25, No. S1 (January 2016): pg. S16-S31. DOI. This article is (C Wiley and permission has been granted for this version to appear in e-Publications@Marquette. Wiley does not grant permission for this article to be further copied/distributed or hosted elsewhere without the express permission from Wiley. 
oral hygiene intervention was performed on all patients by a single experienced dental hygienist. The authors reported no difference in the peri-implant health of patients managed by $0.2 \%$ chlorhexidine mouthrinse or $1 \%$ chlorhexidine gel, but stated that the $1 \%$ gel may be advantageous because it could be applied selectively to affected sites. ${ }^{6}$ Thöne-Mühling et al, ${ }^{15}$ in an RCT on 30 patients with implant crowns and FDPs, investigated whether the addition of chlorhexidine disinfectant (in-office and at-home) provided clinical and microbiological improvement compared to professional oral hygiene maintenance alone (mechanical debridement) in patients with periimplant mucositis and treated chronic periodontitis. Standard periodontal outcomes were recorded at baseline, 1 month, 2 months, 4 months, and at 8 months. Microbial specimens were taken 24 hours and 8 months after application. The authors reported that both treatment modalities resulted in improvement of the clinical parameters and a temporary reduction of the microflora at implants with mucositis, but there were no significant inter-group differences after 8 months.

Paolantonio et $\mathrm{al}^{17}$ in an RCT compared the effectiveness of a $1 \%$ chlorhexidine gel on the internal bacterial contamination of implants with screw-retained abutments. The control group had conventional cement-retained crowns over the implant abutments. In the experimental group, the internal aspect (cavity) of the implant itself was filled with a $1 \%$ chlorhexidine gel before placement of the abutment and restoration. Microbiologic and clinical data were collected at baseline and at 6 months for both groups. The results showed that there was a significant reduction in the total bacterial counts and that periopathogens were detected less frequently in the experimental group. The authors concluded that application of a $1 \%$ chlorhexidine gel inside the implant itself was an effective method to reduce bacterial colonization of the implant cavity over a 6-month period. Magnuson et al, ${ }^{1}$ in an RCT on 28 patients with implantsupported crowns, compared manual brushing and flossing with a conventional string floss to manual brushing and flossing with a water flosser. Bleeding on probing index was used as a primary outcome and was recorded at six sites on each implant at baseline, 14 days, and 30 days. The authors concluded that patients using the water flosser had a statistically significant reduction in bleeding on probing compared to patients using conventional string floss.

Journal of Prosthodontics, Vol 25, No. S1 (January 2016): pg. S16-S31. DOI. This article is (C) Wiley and permission has been granted for this version to appear in e-Publications@Marquette. Wiley does not grant permission for this article to be further copied/distributed or hosted elsewhere without the express permission from Wiley. 


\section{Outcomes related to maintenance using professional intervention}

Six studies (3 RCTs, 3 observational studies) reported on professional intervention related to maintenance of implant-borne restorations. Of these six studies, two RCTs (De Siena et al ${ }^{6}$ and Thöne-Mühling et $\mathrm{al}^{15}$ ) also reported on agent-related outcomes (chlorhexidine) as discussed previously. De Siena et al ${ }^{6}$ concluded that peri-implant mucositis could be successfully treated with professional oral hygiene intervention in conjunction with either $0.2 \%$ chlorhexidine mouth rinse or $1 \%$ chlorhexidine gel topical antimicrobial agent; however, Thöne-Mühling et $\mathrm{al}^{15}$ reported that professional oral hygiene intervention, with or without chlorhexidine, led to an improvement of the clinical parameters of peri-implant health and a temporary reduction of the microflora at implants with mucositis; however, there were no differences after 8 months, indicating that repeated professional intervention is necessary for long-term maintenance of peri-implant health.

In a split-mouth RCT on 15 patients, Mussano et al ${ }^{3}$ compared the peri-implant biological outcomes when professional oral hygiene maintenance was performed using polytetrafluoroethylene (PTFE; Teflon) curettes as hand instrumentation or a glycine powder air polishing system. In this trial, all patients were restored with mandibular two-implant overdentures. Periodontal probing depth, bleeding on probing, and bacterial content within the gingival sulcus were evaluated at baseline, 1 week, and 4 weeks. The authors concluded that glycine powder air polishing was more effective than PTFE curettes for the maintenance of peri-implant soft tissues. Costa et $\mathrm{al}^{8}$ conducted a retrospective study on 80 patients with implantborne crowns and FDPs who had been diagnosed with peri-implant mucositis. In this study, patients were retrospectively divided into two groups: the maintenance group had an average of 5.6 visits during the 5-year maintenance period, while the nonmaintenance group had no professional recall visits. Using standard peri-implant health outcomes, the authors concluded that for patients with peri-implant mucositis, preventive professional maintenance resulted in significantly improved periodontal outcomes compared to patients with no professional maintenance.

Journal of Prosthodontics, Vol 25, No. S1 (January 2016): pg. S16-S31. DOI. This article is @ Wiley and permission has been granted for this version to appear in e-Publications@Marquette. Wiley does not grant permission for this article to be further copied/distributed or hosted elsewhere without the express permission from Wiley. 
Corbella et $\mathrm{al}^{12}$ conducted a prospective cohort study on 60 patients to assess the outcomes of a professional maintenance protocol on patients with immediately loaded implant-supported complete FDPs. In this study, a rigorous professional and at-home maintenance regimen was implemented for all patients. The professional maintenance comprised electric and manual devices for debridement of plaque and calculus from the implant neck and prosthetic surfaces, and the use of interdental floss for removal of plaque and calculus on mesial and distal surfaces of tilted implant necks. For the at-home maintenance regimen, patients were asked to use a $0.2 \%$ chlorhexidine rinse, a soft toothbrush on prosthesis surfaces, a small diameter plastic-coated soft-bristle interdental brush, a medium diameter plastic-coated soft-bristle interdental brush, and a spongy interdental floss. All these oral hygiene aids were to be used at different time points from commencement of surgery to postinsertion of final prosthesis for a lifelong regimen. The mean observation time was 18.3 months (ranging from 6 months to 5 years). During this time, the researchers found that frequency of plaque and bleeding indexes decreased over time. Probing depth remained stable $(2.46 \pm$ $0.5 \mathrm{~mm}$ at 4 years), and the authors concluded that the adoption of a systematic hygiene protocol was effective in controlling plaque accumulation and clinical attachment loss and in reducing the incidence of peri-implant mucositis. Rentsch-Kollar et al ${ }^{13}$ conducted a long-term retrospective study on 101 patients with maxillary and mandibular overdentures where all patients had a follow-up period of more than 10 years. Patients in this study had high compliance rates when seen for professional recall visits conducted at 6-month intervals, when biological and mechanical maintenance of the implant overdentures were performed. This included cleaning of the implants, abutments, and overdentures (biological maintenance); replacement of loose, broken, and lost components and/or repair and remaking of the prosthesis (mechanical maintenance). Based on favorable results, the authors concluded that regular professional care could be provided for aging populations with implant overdentures, where implant and prosthetic survival is high, but regular professional maintenance must be provided, which may result in a considerable number of visits.

Journal of Prosthodontics, Vol 25, No. S1 (January 2016): pg. S16-S31. DOI. This article is @ Wiley and permission has been granted for this version to appear in e-Publications@Marquette. Wiley does not grant permission for this article to be further copied/distributed or hosted elsewhere without the express permission from Wiley. 
NOT THE PUBLISHED VERSION; this is the author's final, peer-reviewed manuscript. The published version may be accessed by following the link in the citation at the bottom of the page.

\section{Discussion}

The aim of this systematic review was to examine the current scientific evidence on patient recall and maintenance of implant-borne fixed and removable restorations, and to identify and compare existing patient care regimens with the goal of improving oral health. An additional purpose was to examine areas of deficiency in the current scientific evidence and provide recommendations for future studies. It is important to note that the focus of this systematic review was on articles that provided data on patient recall and maintenance regimens on periodontally stable/healthy patients. Management of patients with peri-implant disease (such as "peri-implantitis") or other diseases is outside the scope of this systematic review. Similarly, management of patients with complicating medical issues, such as diabetes or being an active smoker, is outside the scope of this review. Although implantborne restorations are increasingly accepted and recommended throughout the world, there is little guidance for the clinician or patient on how to maintain implant-borne restorations. Numerous articles in the literature have previously addressed prosthetic and biologic complications associated with implant restorations; however, few articles have suggested recall and professional and at-home maintenance regimens to prevent and manage these complications.

In this systematic review, patient recall and maintenance (professional and homecare) regimens were divided into three elements: (1) outcomes related to patient-specific restorative treatment; (2) outcomes related to maintenance using oral topical agents and hygiene aids; and (3) outcomes related to maintenance using professional intervention. The authors believe that any patient recall and maintenance (professional and homecare) regimen on implant-borne restorations should incorporate these three elements, as they are all necessary to ensure a successful long-term outcome. Furthermore, unlike tooth-borne restorations, implant-borne restorations also require professional mechanical maintenance to manage anticipated and un-anticipated consequences and complications of treatment. For outcomes related to patient-specific restorative treatment, two RCTs and three observational studies discussed professional mechanical maintenance and confirmed the fact that irrespective of the type of implant-borne restoration, professional

Journal of Prosthodontics, Vol 25, No. S1 (January 2016): pg. S16-S31. DOI. This article is @ Wiley and permission has been granted for this version to appear in e-Publications@Marquette. Wiley does not grant permission for this article to be further copied/distributed or hosted elsewhere without the express permission from Wiley. 
maintenance is necessary; however, the type of treatment and type of implant-borne restoration can affect the nature and frequency of needed professional maintenance and homecare regimens. For outcomes related to maintenance using oral topical agents and hygiene aids, eight RCTs and three observational studies successfully demonstrated that the tested agent (electric toothbrush, interdental brush, chlorhexidine, triclosan, propolis, water flossers) was effective in the professional and homecare maintenance protocol. Similarly, for outcomes related to maintenance using professional intervention, three RCTs and three observational studies successfully demonstrated that professional intervention for biological maintenance was effective for various types of implant-borne restorations. This knowledge is valuable for clinicians and patients when choosing the best agent(s) in conjunction with the professional intervention (biological and mechanical) and at-home maintenance for a given implant-borne restoration.

It is remarkable that 12 of 20 included studies reported on edentulous patients with implant-supported removable overdentures or fixed prostheses. Most of the patients included in these studies were older and geriatric patients. Results from these studies unequivocally showed that implant-borne removable and fixed prostheses require lifelong dental professional maintenance to provide biological and mechanical maintenance. With an increase in the use of implant therapy in aging populations across the world, the finding of lifelong need for professional maintenance may have numerous implications for geriatric dental public health policy worldwide.

The predetermined inclusion criteria for this systematic review were broad to permit the inclusion of as many articles as possible. Therefore, the search terms were expansive to maximize the selection choices from the list of articles. Scrutiny of all articles was performed by both investigators to decrease errors during the review process and minimize selection bias of included articles. Articles determined for exclusion in the full-text analysis stage were analyzed in-depth and debated with predetermined criteria before finalizing inclusion or exclusion. The search dates were restricted to the past 10 years in order to identify evidence from current best practices, as the field of implant dentistry is recognized to be rapidly evolving. Incorporating older studies with older restorative/prosthetic materials as well as 
outdated oral hygiene aids and practices may not be applicable to contemporary dental practice; however, it is remarkable that 15 of 20 included studies were conducted in the past 5 years. Additionally, 16 of 20 studies were conducted in Europe and 1 study was conducted in the United States. A majority of studies included in this review were conducted in a university setting, and only three studies from a private practice setting. The impact of these disparities on the extrapolation of these research findings to the general population is unknown.

Although this systematic review satisfied most PRISMA guidelines, there are some limitations to this review. First, some aspects of the results section were not applicable or amenable to the PRISMA checklist. Second, due to the nature of the topic and PICO question posed in this systematic review, the authors did not find significant quantitative data. Therefore, no statistical analysis was performed. Third, the selection of all articles in this review was restricted to peer-reviewed journals of the English language literature. Although limiting the electronic and hand searches to English minimized problems of interpretation, there may have been a potential for bias, if a substantial number of articles in languages other than English exist; however, a recent empirical study has shown minimal consequences of exclusion or inclusion of trials published in nonEnglish languages on combined effect estimates in meta-analyses of RCTs. ${ }^{39}$ Fourth, given the nature of this topic and the PICO question posed, only articles with a primary focus on patient recall and maintenance were included in the electronic search process. Like most systematic reviews, despite an exhaustive search process, it is possible that the authors failed to identify some articles in the search process. ${ }^{40}$ Gray literature was not considered in this systematic review because articles of this type are usually non-peer reviewed, with a potential for biased information or information that is restricted for use. ${ }^{41}$ Additionally, published trials tend to be larger and show an overall greater treatment effect than gray trials. ${ }^{42}$ However, it is unknown whether incorporation of these omitted articles would change the conclusions of this systematic review. It can be argued that including articles with a focus on implant complications may have offered additional data on professional maintenance of implant-borne restorations; however, previous systematic reviews conducted on this topic have all revealed minimal information on patient recall, professional, and at-home maintenance regimens, to prevent and 
manage these complications. ${ }^{34,35}$ Therefore, to maintain homogeneity in the search process, the authors of this systematic review selected only articles whose primary focus was on recall and maintenance of implant-borne restorations. It is unknown whether incorporation of articles related to implant complications would change the conclusions of this systematic review.

This systematic review identified minimal evidence related to patient recall regimens for removable and fixed implant-borne restorations. Most studies had a recall regimen to satisfy the study's primary objectives and no study compared two different recall regimens for implant-borne restorations. Also, the anticipated implantborne restorations of interest in this study were implant-supported single crowns, implant-supported partial FDPs, implant-supported complete FDPs, implant-supported partial RDPs, and implantsupported complete RDPs; however, no studies in this systematic review reported on recall and maintenance of patients with implantsupported partial RDPs. Most data were restricted to implantsupported complete fixed and removable dental prostheses. Given the small number of studies in this systematic review, the authors did not restrict the inclusion criteria to only RCTs, nor did they perform a risk of bias analysis on any of the included studies (as typically done in Cochrane systematic reviews), because this would have eliminated most selected studies and resulted in an inconclusive and ineffectual conclusion from this systematic review. This would be of little benefit to clinicians and patients. Similarly, no comparison was made for studies that reported support by the manufacturers versus studies that did not receive support. To the authors' best knowledge, this is the first systematic review on recall and maintenance of patients with implant-borne restorations and serves to provide baseline information on this topic and highlights the deficiencies of studies on this important topic as well as insights for development of future studies on this topic.

\section{Conclusions}

There is minimal evidence related to recall regimens in patients with implant-borne removable and fixed restorations; however, there is considerable evidence demonstrating that patients with implant-

Journal of Prosthodontics, Vol 25, No. S1 (January 2016): pg. S16-S31. DOI. This article is @ Wiley and permission has been granted for this version to appear in e-Publications@Marquette. Wiley does not grant permission for this article to be further copied/distributed or hosted elsewhere without the express permission from Wiley. 
borne removable and fixed restorations require a lifelong professional recall regimen to provide biological and mechanical maintenance customized to each patient's treatment. Current evidence also demonstrates that the use of specific oral hygiene aids (electric toothbrush, interdental brush, water flossers) and oral topical agents (chlorhexidine and triclosan) can improve professional and at-home biological maintenance of implant-borne restorations. The characteristics of the treatment (type of prosthesis, type of prosthetic components, and type of restorative/prosthetic materials) can affect the professional mechanical maintenance and homecare regimens. Furthermore, due to the heterogeneity of patient populations, restorations, and treatment needs, the evidence compels forethought of creating clinical practice guidelines for recall and maintenance of patients with implant-borne dental restorations.

\section{References}

${ }^{1}$ Magnuson B, Harsono M, Stark PC, et al: Comparison of the effect of two interdental cleaning devices around implants on the reduction of bleeding: a 30-day randomized clinical trial. Compend Contin Educ Dent 2013;34 Spec No 8:2-7

${ }^{2}$ Morawiec T, Dziedzic A, Niedzielska I, et al: The biological activity of propolis-containing toothpaste on oral health environment in patients who underwent implant-supported prosthodontic rehabilitation. Evid Based Complement Alternat Med 2013;2013:704947

${ }^{3}$ Mussano F, Rovasio S, Schierano G, et al: The effect of glycine-powder airflow and hand instrumentation on peri-implant soft tissues: a splitmouth pilot study. Int J Prosthodont 2013;26:42-44

${ }^{4}$ Swierkot $\mathrm{K}$, Brusius M, Leismann D, et al: Manual versus sonic-powered toothbrushing for plaque reduction in patients with dental implants: an explanatory randomised controlled trial. Eur J Oral Implantol 2013;6:133-144

${ }^{5}$ Zou D, Wu Y, Huang W, et al: A 3-year prospective clinical study of telescopic crown, bar, and locator attachments for removable four implant-supported maxillary overdentures. Int J Prosthodont 2013;26:566-573

${ }^{6}$ De Siena F, Francetti L, Corbella S, et al: Topical application of $1 \%$ chlorhexidine gel versus $0.2 \%$ mouthwash in the treatment of periimplant mucositis. An observational study. Int J Dent Hyg 2013;11:4147

${ }^{7}$ Chongcharoen N, Lulic M, Lang NP: Effectiveness of different interdental brushes on cleaning the interproximal surfaces of teeth and implants:

Journal of Prosthodontics, Vol 25, No. S1 (January 2016): pg. S16-S31. DOI. This article is (C) Wiley and permission has been granted for this version to appear in e-Publications@Marquette. Wiley does not grant permission for this article to be further copied/distributed or hosted elsewhere without the express permission from Wiley. 
NOT THE PUBLISHED VERSION; this is the author's final, peer-reviewed manuscript. The published version may be accessed by following the link in the citation at the bottom of the page.

a randomized controlled, double-blind cross-over study. Clin Oral Implants Res 2012;23:635-640

${ }^{8}$ Costa FO, Takenaka-Martinez S, Cota LO, et al: Peri-implant disease in subjects with and without preventive maintenance: a 5-year follow-up. J Clin Periodontol 2012;39:173-181

${ }^{9}$ Fischer K, Stenberg T: Prospective 10-year cohort study based on a randomized, controlled trial (RCT) on implant-supported full-arch maxillary prostheses. Part II: prosthetic outcomes and maintenance. Clin Implant Dent Related Res 2013;15:498-508

${ }^{10}$ Katsoulis J, Brunner A, Mericske-Stern R: Maintenance of implant-supported maxillary prostheses: a 2-year controlled clinical trial. Int J Oral Maxillofac Implants 2011;26:648-656

${ }^{11}$ Akça K, Cehreli MC, Uysal S: Marginal bone loss and prosthetic maintenance of bar-retained implant-supported overdentures: a prospective study. Int J Oral Maxillofac Implants 2010;25:137-145

${ }^{12}$ Corbella S, Del Fabbro M, Taschieri S, et al: Clinical evaluation of an implant maintenance protocol for the prevention of peri-implant diseases in patients treated with immediately loaded full-arch rehabilitations. Int J Dent Hyg 2011;9:216-222

${ }^{13}$ Rentsch-Kollar A, Huber S, Mericske-Stern R: Mandibular implant overdentures followed for over 10 years: patient compliance and prosthetic maintenance. Int J Prosthodont 2010;23:91-98

${ }^{14}$ Sreenivasan $\mathrm{PK}$, Vered $\mathrm{Y}$, Zini A, et al: A 6-month study of the effects of $0.3 \%$ triclosan/copolymer dentifrice on dental implants. J Clin Periodontol 2011;38:33-42

${ }^{15}$ Thöne-Mühling M, Swierkot K, Nonnenmacher C, et al: Comparison of two full-mouth approaches in the treatment of peri-implant mucositis: a pilot study. Clin Oral Implants Res 2010;21:504-512

${ }^{16}$ Kleis WK, Kämmerer PW, Hartmann S, et al: A comparison of three different attachment systems for mandibular two-implant overdentures: oneyear report. Clin Implant Dent Relat Res 2010;12:209-218

${ }^{17}$ Paolantonio M, Perinetti G, D'Ercole S, et al: Internal decontamination of dental implants: an in vivo randomized microbiologic 6-month trial on the effects of a chlorhexidine gel. J Periodontol 2008;79:1419-1425

${ }^{18}$ Ramberg $P$, Lindhe J, Botticelli $D$, et al: The effect of a triclosan dentifrice on mucositis in subjects with dental implants: a six-month clinical study. $J$ Clin Dent 2009;20:103-107

${ }^{19}$ Rasperini G, Pellegrini G, Cortella A, et al: The safety and acceptability of an electric toothbrush on peri-implant mucosa in patients with oral implants in aesthetic areas: a prospective cohort study. Eur J Oral Implantol 2008;1:221-228

Journal of Prosthodontics, Vol 25, No. S1 (January 2016): pg. S16-S31. DOI. This article is @ Wiley and permission has been granted for this version to appear in e-Publications@Marquette. Wiley does not grant permission for this article to be further copied/distributed or hosted elsewhere without the express permission from Wiley. 
NOT THE PUBLISHED VERSION; this is the author's final, peer-reviewed manuscript. The published version may be accessed by following the link in the citation at the bottom of the page.

${ }^{20}$ Vandekerckhove B, Quirynen M, Warren PR, et al: The safety and efficacy of a powered toothbrush on soft tissues in patients with implantsupported fixed prostheses. Clin Oral Investig 2004;8:206-210

${ }^{21}$ Boggs A, Maurer S, Mourino A, et al: Recall intervals: effect on treatment needs- a retrospective study. J Clin Pediatr Dent 1996;20:119-122

${ }^{22}$ Maurer S, Boggs A, Mourino A, et al: Recall intervals: effect on treatment needs of the handicapped patient- a retrospective study. J Clin Pediatr Dent 1996;20:123-126

${ }^{23}$ Wang $N$, Marstrander $P$, Holst $D$, et al: Extending recall intervals: effect on resource consumption and dental health. Community Dent Oral Epidemiol 1992;20:122-124

${ }^{24}$ Patel S, Bay C, Glick M: A systematic review of dental recall intervals and incidence of dental caries. J Am Dent Assoc 2010;14:527-539

${ }^{25}$ Teich ST. Risk Assessment-Based Individualized Treatment (RABIT): a comprehensive approach to dental patient recall. J Dent Educ $2013 ; 77: 448-457$

${ }^{26}$ Sheiham A: Is there a scientific basis for six-monthly dental examinations? Lancet $1977 ; 2: 442-444$

${ }^{27}$ Featherstone J, Singh S, Curtis DA: Caries risk assessment and management for the prosthodontic patient. J Prosthodont 2011;20:2-9

${ }^{28}$ Cheng J, Chaffee BW, Cheng NF, et al: Understanding treatment effect mechanisms of the CAMBRA randomized trial in reducing caries increment. J Dent Res 2015;94:44-51

${ }^{29} \mathrm{Kye}$ W, Davidson R, Martin J, et al: Current status of periodontal risk assessment. J Evid Based Dent Pract 2012;12:2-11

${ }^{30}$ Riley $\mathrm{P}$, Worthington HV, Clarkson JE, et al: Recall intervals for oral health in primary care patients. Cochrane Database Syst Rev 2013 Dec 19;12:CD004346

${ }^{31}$ Ricci-Cabello I, Ruiz-Perez I, Rojas-Garcia A, et al: Characteristics and effectiveness of diabetes self-management educational programs targeted to racial/ethnic minority groups: a systematic review, metaanalysis and meta-regression. BMC Endocr Disord 2014;19:14-60

${ }^{32}$ Pjetursson $B E$, Thoma $D$, Jung $R$, et al: $A$ systematic review of the survival and complication rates of implant-supported fixed dental prostheses (FDP's) after a mean observation period of at least 5 years. Clin Oral Implants Res 2012;6:22-38

${ }^{33}$ Wittneben J, Buser D, Salvi GE, et al: Complication and failure rates with implant-supported fixed dental prostheses and single crowns: a 10year retrospective study. Clin Implant Dent Relat Res 2014;16:356364

${ }^{34}$ Pjetursson $\mathrm{BE}$, Bragger $\mathrm{U}$, Lang NP, et al: Comparison of survival and complication rates of tooth-supported fixed dental prostheses (FDPs)

Journal of Prosthodontics, Vol 25, No. S1 (January 2016): pg. S16-S31. DOI. This article is (C) Wiley and permission has been granted for this version to appear in e-Publications@Marquette. Wiley does not grant permission for this article to be further copied/distributed or hosted elsewhere without the express permission from Wiley. 
NOT THE PUBLISHED VERSION; this is the author's final, peer-reviewed manuscript. The published version may be accessed by following the link in the citation at the bottom of the page.

and implant-supported FDPs and single crowns (SCs). Clin Oral Impl Res 2007;18:97-113

${ }^{35}$ Goodacre CJ, Bernal G, Rungcharassaeng K, et al: Clinical complications with implants and implant prostheses. J Prosthet Dent 2003;90:121132

${ }^{36}$ Pjetursson $\mathrm{BE}$, Helbling $\mathrm{C}$, Weber HP, et al: Peri-implantitis susceptibility as it relates to periodontal therapy and supportive care. Clin Oral Implants Res 2012;23:888-894

${ }^{37}$ Lindquist LW, Carlsson GE, Jemt TA: A prospective 15-year follow-up study of mandibular fixed prostheses supported by osseointegrated implants. Clinical results and marginal bone loss. Clin Oral Implants Res $1996 ; 7: 329-336$

38Moher D, Liberati A, Tetzlaff J: PRISMA Group. Preferred reporting items for systematic reviews and meta-analyses: the PRISMA Statement. J Clin Epidemiol 2009;62:1006-1012

${ }^{39}$ Egger $M$, Jüni $P$, Bartlett $C$, et al: How important are comprehensive literature searches and the assessment of trial quality in systematic reviews? Empirical study. Health Technol Assess 2003;7:1-76.

${ }^{40}$ Savoie I, Helmer D, Green CJ, et al: Beyond Medline: reducing bias through extended systematic review search. Int J Technol Assess Health Care 2003; 19:168-178

${ }^{41}$ Auger CP (ed): Information Sources in Grey Literature (ed 2). London, Bowker-Saur, 1989

${ }^{42}$ Hopewell S, McDonald S, Clarke M, et al: Grey literature in meta-analyses of randomized trials of health care interventions. Cochrane Database Syst Rev 2007;2:MR000010

Journal of Prosthodontics, Vol 25, No. S1 (January 2016): pg. S16-S31. DOI. This article is @ Wiley and permission has been granted for this version to appear in e-Publications@Marquette. Wiley does not grant permission for this article to be further copied/distributed or hosted elsewhere without the express permission from Wiley. 